\title{
Root system attributes of 12 juvenile indigenous early colonising shrub and tree species with potential for mitigating erosion in New Zealand
}

\author{
M. Marden ${ }^{1 *}$, S. Lambie ${ }^{2}$ and D. Rowan ${ }^{3}$
}

\begin{abstract}
Background: Restoring erosion-prone land with indigenous species, whether by managed reforestation (planting) or by passive natural reversion, is reliant on knowing which species mix is likely to provide the quickest and most effective mitigation against shallow landslides. In turn, this requires knowledge of differences in growth metrics among plant species, particularly during their formative years. This study presents data on the root development and architecture of 12 of New Zealand's commonest early colonising indigenous shrub and tree species. These data are crucial to the development of guidelines and policy for land use conversion and future land management options where unmitigated erosion is of increasing concern.

Methods: In a plot-based field trial, the growth performance of Coprosma robusta (karamū), Plagianthus regius (ribbonwood), Sophora tetraptera (kōwhai), Pittosporum eugenioides (lemonwood), Pittosporum tenuifolium (kōhūhū), Hoheria populnea (lacebark), Myrsine australis (māpou), Pseudopanax arboreus (fivefinger), Cordyline australis (cabbage tree), Knightia excelsa (rewarewa), Leptospermum scoparium (mānuka), and Coriaria arborea (tutu) was measured annually over five consecutive years.

Results: Eleven species developed a heart-shaped root system and Cordyline australis, a tap-rooted system. By year 5 , the root/shoot ratio ranged between 0.24 and $0.44,>99.5 \%$ of the total root mass and root length of all species was confined to within $0.5 \mathrm{~m}$ of the ground surface and $>73 \%$ within 1 radial metre of the root bole. Regressions between root collar diameter (RCD over bark) and root length were highly significant $(P<0.001)\left(r^{2}\right.$ values $\left.0.55-0.92\right)$, as were regressions for root biomass ( $r^{2}$ values $\left.0.31-0.97\right)$. RCD fitted best for below-ground biomass ( $r^{2}$ values $\left.0.67-0.94\right)$.

Conclusions: The species with the greatest potential for mitigating shallow forms of erosion were Pittosporum eugenioides, Plagianthus regius, Coriaria arborea, Pittosporum tenuifolium, Hoheria populnea, Sophora tetraptera, and Cordyline australis. New data on differences in root metrics between species have improved our understanding of their strengths and limitations, alone or as mixed plantings, and of the time (years after planting) and density of plantings required to achieve a successful erosion control outcome. Modelling root-soil reinforcement and the role of root systems in mitigating the initiation of shallow slope failures should include roots $>1 \mathrm{~mm}$ in diameter.
\end{abstract}

Keywords: Root system metrics and architecture, Juvenile seral indigenous species, Erosion mitigation potential

\footnotetext{
* Correspondence: mardenm@landcareresearch.co.nz

${ }^{1}$ Landcare Research, Gisborne, New Zealand

Full list of author information is available at the end of the article
} 


\section{Background}

Seral shrub and tree species make up a significant component of New Zealand's indigenous woody vegetation cover and are found across a wide range of climate, soil type, and geomorphic land forms. They typically comprise understorey within areas of indigenous and exotic forest and occur as buffers along stream corridors (riparian zone) and the margins of lakes. They are also early colonisers following the abandonment of marginal pastoral land and make up a significant component of the groundcover species that germinate following the retirement of uneconomic areas of short-rotation exotic (predominantly Pinus radiata D.Don) forest.

A number of government-funded schemes (e.g. Afforestation Grant Schemes (Ministry for Primary Industries 2015a) and the Permanent Forest Sink Initiative (Ministry for Primary Industries 2015b) have been introduced to encourage the establishment of new areas of forest (exotic and indigenous) and to facilitate natural reversion of shrubland areas. These schemes, together with a recently announced government goal to plant one billion trees over the next 10 years, will likely target $\sim 1.45$ million ha of steep, erosion-prone pastoral hill country considered marginal for long-term agriculture and/or areas of short-rotation exotic forest where the erosion risk is high and the land better suited to transitioning to a permanent indigenous shrubland or forest (Trotter et al. 2005). In such high-risk areas, woody indigenous shrubland plays an important role in mitigating erosion (Marden and Rowan 1993; Ministry for Primary Industries 2015a, 2015b, 2016). It also brings additional non-wood benefits and services including boosting regional economic development, increasing forest carbon stocks, and improvements in water quality. Qualifying species include all indigenous colonisers with Leptospermum scoparium (mānuka (Forster et Forster f.)) currently being planted on a large scale for honey production and pharmaceutical purposes and, together with kānuka (Kunzea ericoides var. ericoides (A. Rich) J. Thompson), account for $\sim 70 \%$ of the total area of regenerating indigenous shrubland in New Zealand (Ministry for Primary Industries 2017).

Data on relative growth performance are essential for an assessment of the soil-root reinforcement potential and hydrological benefits of New Zealand's many other indigenous seral species in mitigating shallow landslides and other forms of surficial erosion. Particularly important is knowledge of their root systems during their early growth period when juvenile plantings are at their most vulnerable to the initiation of hillslope failure.

Other than destructive sampling, there are few techniques available to establish architectural differences in root system attributes (depth, spread, spatial arrangement) among species or to accurately quantify the apportionment of a plant's total biomass to its root system.
The use of non-invasive techniques (such as ground-penetrating radar) is limited to coarse root systems (Hruska et al. 1999), and the fine-root components are particularly difficult and expensive to measure accurately. Furthermore, studies that have attempted to extract the majority of the below-ground root biomass often exclude the root bole (Will 1966; Heth and Donald 1978; Watson and O'Loughlin 1990) and therefore underestimate below-ground biomass (BGB). Thus, data derived from whole-root system excavations are the most reliable for inclusion in slope stability and/or soil reinforcement models (e.g. Schwarz et al. 2010). Such data are also an essential requirement for the development of allometric relationships for above- and below-ground biomass, many of which suffer from incomplete data (Phillips et al. 2012). Interspecies differences in the timing and amount of the total plant biomass apportioned to root systems are known to occur, but species-specific allocations of dry matter to roots are generally poorly documented (Korner 1998). Previous authors (e.g. Cairns et al. 1997; Coomes et al. 2002) have suggested a value of $20 \%$ can be applied generally, but in a recent study that destructively sampled eight of New Zealand's dominant conifer and broadleaved forest species, it was shown that the proportion of total plant biomass allocated to the respective root systems (inclusive of the stump) of juvenile saplings was species-specific. Furthermore, it varied between 21 and $42 \%$ and decreased with increasing tree age (Marden et al. 2018, in press). These results show that more age-related and species-specific studies of biomass allocation in New Zealand's indigenous seral and forest species are needed before a figure of $20 \%$ can be generally accepted.

Marden et al. (2005) provided annual (1-5 years) root growth data for the species presented in this paper, but species-specific allometric relationships established for total BGB, total root biomass, and total root length have not previously been presented. These authors also discussed the potential effectiveness and/or limitation of the root attributes of these species for improving stream bank stability. However, inter-species differences in the spatial distribution of root biomass and length and of the different root diameter size classes, in relation to their potential role in mitigating the incidence of shallow landslides and deeper forms of slope failure (earthflows and rotational slumps), warrant further discussion.

Differences in species growth rates, together with knowledge of their allometry, have the potential to improve our understanding of the influence that different species mixes and planting densities have on the time required (years after planting) for soil-root reinforcement to become effective in mitigating shallow, storm-initiated landslides. Therefore, root metric data for the final year only of a 5 -year trial are presented here in order to best demonstrate relationships between root growth performance and 
soil-root reinforcement and of the timing (years after planting) when plantings are likely to provide an effective erosion mitigation service. The findings from this analysis are likely to be of greatest relevance to the development of guidelines and policy towards actively managing land use change from farmland to indigenous woody vegetation cover and equally for assessing the erosion mitigation potential of shrubland species on land designated as suitable for passive reversion as a pathway to permanent indigenous forest.

The primary goals of this paper are to: (i) provide a first-ever description and classification of the root architecture of 12 of New Zealand's more common early colonising species used predominantly in land use conversion and environmental restoration projects; (ii) present species-specific allometric equations with a focus on root biomass and length and the spatial distribution of roots with increasing distance from and below the root bole; and (iii) assess the potential effectiveness of different species mixes and planting strategies in mitigating shallow landslides and other forms of surficial erosion based on the growth performance of 5-year-old plantings.

\section{Methods}

\section{Study site}

The trial site was established in 1999 on a low-lying, even-surfaced alluvial terrace located adjacent to the Taruheru River in Gisborne City (Fig. 1) and was used subsequently to measure the plant growth performance of: (i) eight of New Zealand's more common indigenous conifer and broadleaved species (Marden et al. 2018, in press); (ii) different clones of poplar and willow (Phillips et al. 2014); and (iii) a range of exotic forest species (Phillips et al. 2015). Temperatures over summer average $23^{\circ} \mathrm{C}$ and over winter $12{ }^{\circ} \mathrm{C}$. Mean annual rainfall is $1000 \mathrm{~mm}$ and mean evapotranspiration $985 \mathrm{~mm}$, with moderate soil moisture deficits experienced from November to February (New
Zealand Meteorological Service 1986). The soil is free-draining, Typic Sandy Brown soil (Hewitt 2010). Drip irrigation was installed to ensure survival of the plants in the event that drought jeopardised the longer-term aims of this trial, but this was not used.

The soil has no physical or chemical impediments to root development to about $1.2 \mathrm{~m}$ depth, other than a variable-depth water table that fluctuates between > $1.5 \mathrm{~m}$ depth to within $\sim 0.2 \mathrm{~m}$ of the surface (Phillips et al. 2014) for short and infrequent periods following prolonged and heavy rainfall.

\section{Trial design}

The aim was to collect annual above- and below-ground growth performance data for five consecutive years. It was not considered practical or environmentally acceptable to source plants directly from their natural environment, so containerised plants were purchased from a local plant nursery. Containers consisted of 1.2-L polythene bags $(0.12 \mathrm{~m}$ deep $\times 0.10 \mathrm{~m}$ diameter $)$ filled with a 50:50 mix of bark and pumice. To minimise root disturbance, seedlings were planted with the soil attached. Root binding was minimal and tap-root length did not exceed the depth of the planting bag, so root pruning prior to planting was not required.

In preparation for planting, the trial site $(50 \mathrm{~m} \times$ $20 \mathrm{~m}$ ) was tilled and weed mat was laid down (Fig. 1). The site was subdivided into three blocks and planted in a day. A randomised block design was used, with equal numbers of each species in each block. Blocks 1 and 2 (plants to be extracted 1 and 2 years after planting (i.e. at age 3 and 4 years, respectively)) were planted at $1.0 \mathrm{~m}$ spacing and block 3 (plants to be extracted 3 years after planting (i.e. at age 5)) at $1.5-2.0 \mathrm{~m} \mathrm{spa}$ cing to allow for increases in canopy and root growth during the course of the trial.
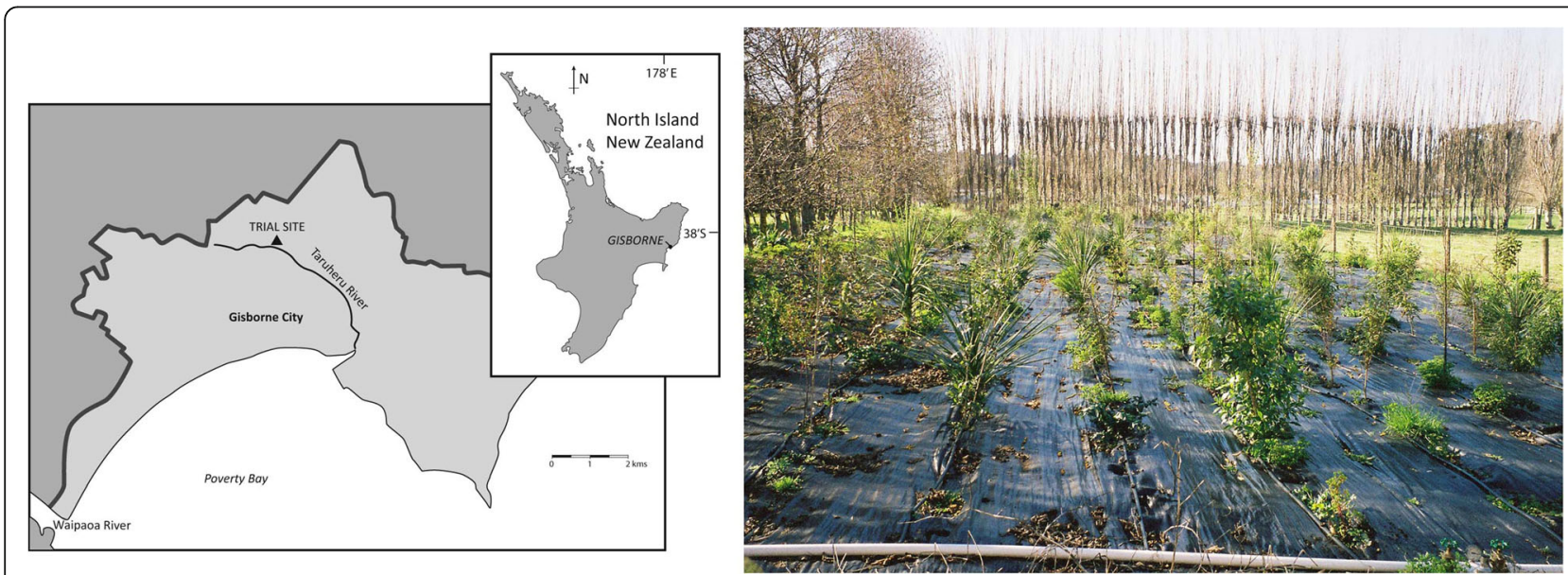

Fig. 1 Location map with photograph of 3-year-old plants at the trial site 


\section{Species selection}

Species selection was undertaken using published information from the Allan Herbarium (2000) and included some of the more common seral varieties associated with land identified as no longer sustainable as pasture or exotic forest but better suited to transitioning to a permanent indigenous vegetation cover. The chosen species include Coprosma robusta (karamu (Raoul)), Plagianthus regius (ribbonwood (Poit.) Hochr.), Sophora tetraptera (kowhai (J. S. Miller)), Pittosporum eugenioides (lemonwood (Cunn.)), Pittosporum tenuifolium (kōhūhū (Gaertner)), Hoheria populnea (lacebark (Cunn.)), Myrsine australis (mapou (A. Rich) Allan), Pseudopanax arboreus (fivefinger ((Murray) Philipson)), Cordyline australis (cabbage tree ((Forster f.) Endl.)), Knightia excelsa (rewarewa (R. Br.)), Leptospermum scoparium (mānuka (Forster et Forster f.)), and Coriaria arborea (tutu (R. Lindsay)) (Table 1).

\section{Data collection}

Plant age was designated as 0 years at the date each species was pricked out into containers. Data for 1and 2-year-old seedlings were collected by destructively partitioning the containerised plants into their component parts. For the field component of the trial, 2-year-old containerised plants were established at the trial site and on-grown for three more years. Compressed air $(240 \mathrm{kPa})$ delivered through an air lance was used to excavate 3-, 4-, and 5-year-old bare-rooted plants as this process removed the soil from the root systems without damage or significant loss of the fibrous root mass. The aim was to sample 10 plants per species per year. Frost, insect attack, and windthrow accounted for the shortfall in sample size for some of the species.

Root collar diameter (RCD over bark) was measured at ground level before removing the plants from the trial site. Root system extraction and measurement methods followed well-established procedures (e.g. Watson et al. 1999; Marden et al. 2005; Phillips et al. 2014, 2015). Mean root depth and spread of the lateral roots, hereafter referred to as root depth and root spread, were measured in situ (Table 1). Mean root spread was taken as the mean of the maximum root length measured from root tip to root tip in two directions at right angles to each other. Once removed from the ground, the roots were washed to remove adhering soil matter, photographed, then partitioned into root bole (stump) and roots. Root distribution (by mass, length, and diameter size class) relative to the root bole was obtained by systematically dissecting the root systems into $0.5-\mathrm{m}$ radial and depth segments then sorting by diameter size classes $((<1 \mathrm{~mm}$ fibrous) $1-2,2.1-5.0,5.1-10.0,10.1-20.0$, 20.1-50.0 $\mathrm{mm}$ over bark) (Watson and O'Loughlin 1990). Root length within each of the root diameter size classes $>1 \mathrm{~mm}$ was measured by laying pieces of root end to end alongside a tape measure (Watson et al. 1999). A detailed sketch of the plan and side view of the root system of a typical 5-year-old plant of each species is shown in Additional file 1.

Biomass was oven-dried at $100^{\circ} \mathrm{C}$ for $24 \mathrm{~h}$ or until no further weight loss was detectable then weighed to the

Table 1 Trees sampled and mean root growth metrics at year 5

\begin{tabular}{|c|c|c|c|c|c|c|c|}
\hline Species & $\begin{array}{l}\text { Sample } \\
\text { number }\end{array}$ & $\begin{array}{l}\text { Root collar } \\
\text { diameter (mm) }\end{array}$ & $\begin{array}{l}\text { Mean max. root spread } \\
\text { (diameter in m) }\end{array}$ & $\begin{array}{l}\text { Mean total root length } \\
\text { of roots }>1 \mathrm{~mm}(\mathrm{~m})\end{array}$ & $\begin{array}{l}\text { Mean max. } \\
\text { root depth }(\mathrm{m})\end{array}$ & Total BGB (g) & $\begin{array}{l}\text { BGB/AGB } \\
\text { ratio }\end{array}$ \\
\hline Coriaria arborea & 5 & $292.8(71.4)^{d}$ & $2.69(0.27)^{f}$ & $158.82(43.33)^{\text {de }}$ & $0.33(0.02)^{\mathrm{ab}}$ & $2937.5(1118.8)^{f}$ & $0.33(0.05)^{\mathrm{abc}}$ \\
\hline Myrsine australis & 10 & $28.1(2.6)^{\mathrm{a}}$ & $0.90(0.07)^{\mathrm{a}}$ & $20.62(3.17)^{\mathrm{a}}$ & $0.21(0.01)^{a}$ & $156.8(26.8)^{a}$ & $0.44(0.04)^{c}$ \\
\hline Pseudopanax arboreus & 8 & $51.9(6.4)^{\mathrm{ab}}$ & $1.48(0.21)^{\mathrm{bc}}$ & $40.33(13.10)^{\mathrm{abc}}$ & $0.26(0.02)^{\mathrm{ab}}$ & $467.8(143.9)^{\mathrm{abcd}}$ & $0.31(0.02)^{\mathrm{abc}}$ \\
\hline Sophora tetraptera & 10 & $44.6(4.4)^{\mathrm{ab}}$ & $1.99(0.19)^{\text {cde }}$ & $79.72(16.81)^{\mathrm{abcd}}$ & $0.31(0.06)^{\mathrm{ab}}$ & $859.7(266.6)^{\mathrm{abcde}}$ & $0.40(0.04)^{b c}$ \\
\hline Cordyline australis & 10 & $121.3(8.1)^{c}$ & $2.24(0.09)^{\mathrm{def}}$ & $101.28(10.08)^{b c d}$ & $0.45(0.03)^{c}$ & $2699.3(394.6)^{f}$ & $0.24(0.03)^{a}$ \\
\hline Hoheria populnea & 8 & $60.7(8.4)^{\mathrm{ab}}$ & $2.30(0.22)^{e f}$ & $130.95(24.70)^{\mathrm{abcd}}$ & $0.33(0.03)^{\mathrm{ab}}$ & $\begin{array}{l}1343.2 \\
(358.5)^{\mathrm{abcde}}\end{array}$ & $0.32(0.03)^{\mathrm{abc}}$ \\
\hline Knightia excelsa & 9 & $43.9(4.2)^{\mathrm{ab}}$ & $1.07(0.09)^{\mathrm{ab}}$ & $46.30(8.58)^{\mathrm{abc}}$ & $0.30(0.02)^{\mathrm{ab}}$ & $311.8(55.4)^{\mathrm{ab}}$ & $0.34(0.04)^{\mathrm{abc}}$ \\
\hline Pittosporum tenuifolium & 10 & $55.7(2.2)^{\mathrm{ab}}$ & $2.34(0.17)^{\text {def }}$ & $118.78(13.26)^{\mathrm{cd}}$ & $0.27(0.03)^{\mathrm{ab}}$ & $\begin{array}{l}1216.4 \\
(157.5)^{\mathrm{abcde}}\end{array}$ & $0.31(0.02)^{a b c}$ \\
\hline Pittosporum eugenioides & 10 & $61.0(2.5)^{\mathrm{ab}}$ & $3.16(0.12)^{9}$ & $197.35(21.60)^{\mathrm{e}}$ & $0.28(0.02)^{\mathrm{ab}}$ & $1545.4(147.8)^{\text {bde }}$ & $0.36(0.03)^{\mathrm{abc}}$ \\
\hline Coprosma robusta & 10 & $72.4(6.9)^{\mathrm{ab}}$ & $1.72(0.21)^{\mathrm{cd}}$ & $103.52(17.28)^{\mathrm{abcd}}$ & $0.37(0.05)^{b c}$ & $\begin{array}{l}1317.8 \\
(263.8)^{\text {abcde }}\end{array}$ & $0.28(0.03)^{a b}$ \\
\hline Plagianthus regius & 10 & $85.2(6.8)^{b}$ & $2.62(0.16)^{f}$ & $159.64(39.86)^{d e}$ & $0.38(0.04)^{b c}$ & $1816.5(352.9)^{\mathrm{e}}$ & $0.35(0.03)^{\mathrm{abc}}$ \\
\hline $\begin{array}{l}\text { Leptospermum } \\
\text { scoparium }\end{array}$ & 5 & $34.4(3.0)^{\mathrm{ab}}$ & $1.47(0.27)^{b c}$ & $24.43(4.73)^{\mathrm{ab}}$ & $0.28(0.01)^{\mathrm{ab}}$ & $319.1(65.3)^{\mathrm{abc}}$ & $0.24(0.01)^{\mathrm{a}}$ \\
\hline
\end{tabular}


nearest $0.1 \mathrm{~g}$. The root:shoot ratio was calculated using dry mass.

Over the duration of this trial, 554 individual plants were destructively sampled. Annual measurements of tree height, canopy spread, stem diameter at breast height (DBH) (measured at $1.4 \mathrm{~m}$ above ground level), and above-ground biomass were collected, but these data are not presented in depth in this paper.

\section{Statistical analyses}

Root collar diameter (over bark) was used to establish allometric relationships because seedlings did not reach DBH height until the second year of the trial. The relationship between RCD and either total BGB or the total root biomass of roots $>1$ or $>2 \mathrm{~mm}$ diameter was analysed using two-parameter exponential growth analysis. Total root length for roots $>1$ or $>2 \mathrm{~mm}$ diameter was best modelled using linear regression. All regression analyses were undertaken using SigmaPlot 12.5 (Systat Software, San Jose, CA).

Following regression analysis of total root biomass against RCD for roots $>1$ or $>2 \mathrm{~mm}$ in diameter, a $t$ test (two-tailed, unpaired) was conducted on the slopes of the regression curves to determine if there was a difference in growth characteristics between the two root diameter size classes. In the two-parameter exponential growth equation used $(y=a \exp (b x)$, the slope of the regression is represented by $b$. There was no difference between the slopes of the regression curves $(P=0.867)$ for the $>1-\mathrm{mm}$ roots compared with the $>2$-mm roots with respect to root biomass.

A comparison of the slopes of the regression curves generated using linear regression analyses of RCD and total root length for roots $>1$ or $>2 \mathrm{~mm}$ diameter found that the slope of the curve for roots $>1 \mathrm{~mm}$ was significantly greater $(P=0.006)$ than the slope of the curves for roots $>2 \mathrm{~mm}$. Therefore, root diameter size classes $>1 \mathrm{~mm}$ diameter are included in all linear analyses for total root length and total root biomass.

ANOVA was used to determine the differences between species within below-ground parameters. The Student-Newman-Keuls post hoc analysis (at $P=0.05$ ) was used to determine differences between species means within a year, blocked by replicate. The normality of each analysis was determined by visual assessment of residual plots. Where data exhibited non-normality, they were transformed using the equation $\log _{\mathrm{e}}(x+c)$, where $x$ was the parameter and $c=1$. All ANOVA analyses were conducted using Genstat 12 (VSN International, Hemel Hempstead, UK).

All analyses were considered to be significant if $P=$ 0.05. Data are presented as a mean with standard error of the mean, unless otherwise stated.

\section{Results}

\section{Root system types}

As previously described in Marden et al. (2005) using the descriptive classification of Hinds and Reed (1957), root systems are either tap- or heart-rooted, as follows:

Tap-rooted. The seedling radicle develops into a single or branched, more-or-less vertical, massive root (tap root), from which planes of lateral and horizontally inclined roots develop.

Heart-rooted. These consist of a compact system with many oblique lateral and vertical roots (heart or sinker roots) descending from or near the root bole, generally replacing the tap root.

Lateral roots are long and radially spreading from the tap root, or from the root bole, possibly in two or more plates or strata, whereas sinker roots are those descending more or less vertically from the main laterals at varying distances from the root bole and to depths up to or exceeding that of the tap root (Phillips and Watson 1994).

The only species to develop a tap-rooted system was Cordyline australis, which consisted of a central, tuberous root/rhizome with frequent lateral roots emerging at different depths in the soil profile (Additional file 1). The remaining 11 species developed heart-rooted systems with the early development of multiple and large-diameter roots descending obliquely from the base of the root bole. Also, Plagianthus regius, Pittosporum eugenioides, Coriaria arborea, Cordyline australis, Hoheria populnea, and Pittosporum tenuifolium developed long and thin lateral roots at an early age that, by age 5 years, extended to $>2 \mathrm{~m}$ from the root bole, often with multiple branching at their extremities (Additional file 1). Their horizontal and vertical distribution within the soil profile was highly asymmetric, with large areas of soil devoid of any roots. Conversely, the root systems of Myrsine australis and Knightia excelsa were more compact with a mean root spread of $<1 \mathrm{~m}$. Their roots were typically fibrous, highly branched, and matted (Additional file 1). Myrsine australis and Sophora tetraptera developed sinker roots at between 0.5 and $1.0 \mathrm{~m}$ radial distance from the root bole, which by year 5 had descended to a depth of $\sim 0.15-0.20 \mathrm{~m}$.

\section{Root growth performance}

The best performing of the trialled species had developed a root system with a diameter spread in excess of $2 \mathrm{~m}$ within 5 years of establishment. Pittosporum eugenioides, Coriaria arborea, and Plagianthus regius developed root systems with the widest spread, but they were not significantly different $(P=0.05)$ to that of Cordyline australis and Pittosporum tenuifolium. Conversely, the root system diameters of Myrsine australis $(0.9 \mathrm{~m})$ 
and Knightea excelsa $(1.07 \mathrm{~m})$ were significantly smaller $(P=0.05)$ than those of the remaining species (Table 1).

As might be expected, the species that developed widespread root systems accumulated the most total BGB. The heart-rooted Coriaria arborea (2937.5 g) and tap-rooted Cordyline australis (2699.3 g) accumulated significantly more $B G B$ than did any of the remaining species, while the $B G B$ accumulated by each of the remaining 10 heart-rooted species was not significantly different $(P=0.05)$ from each other (Table 1$)$.

Interestingly, the root/shoot ratio was highest for the smallest-statured Myrsine australis and Sophora tetraptera at $>0.40$ of total plant biomass. These values were not significantly different $(P=0.05)$ from each other or eight of the other trialled species, but they were greater than that of the tap-rooted Cordyline australis and the heart-rooted Leptospermum scoparium (0.24), which surprisingly were not significantly different from each other (Table 1, Fig. 2).

There were also significant species-specific differences in the proportion of the total $\mathrm{BGB}$ allocated between the root bole and roots. For example, $83.2 \%$ of the total BGB of the sole tap-rooted species Cordyline australis was allocated to its tuberous root/rhizome bole. This value was significantly higher $(P=0.05)$ than that allocated to the respective root boles of the heart-rooted species, (Table 2). For 10 of the 11 heart-rooted species, the biomass allocated to the respective root boles (range 24-39\%) was not significantly different in each case but was significantly greater $(P=0.05)$ than that of Myrsine australis (13.2\% of total BGB).

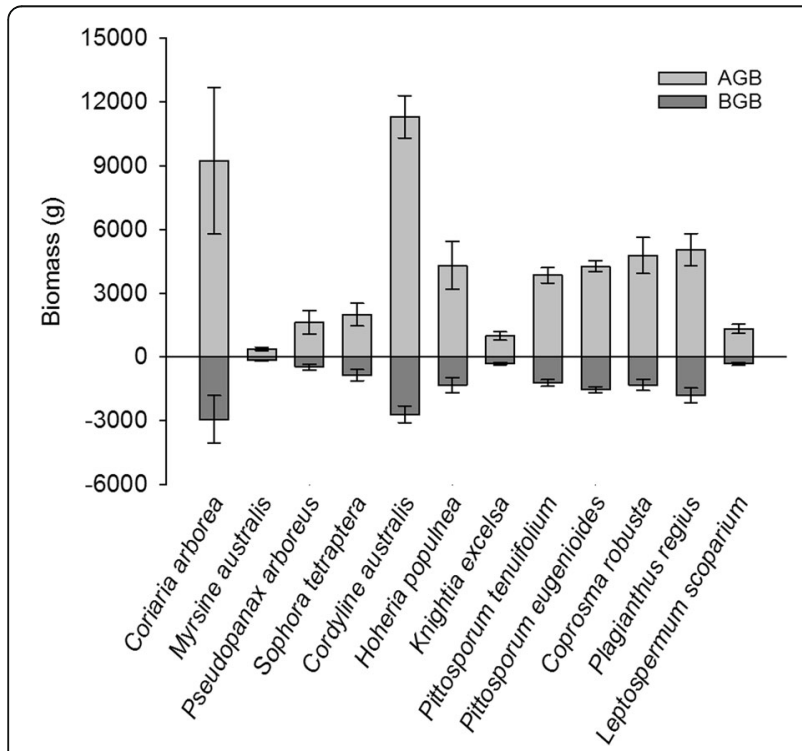

Fig. 2 Plant biomass above- (dark bars) and below-ground (light bars) in year 5 . Error bars represent one standard error of the mean. Bars within each parameter with a different letter were significantly different $(P=0.05)$
Analysis of root biomass distribution relative to radial distance from the root bole showed that more than half of their respective root mass was confined to within $0.5 \mathrm{~m}$ of the root bole for all 12 species. Furthermore, the more compact root systems of Myrsine australis, Knightia excelsa, and Leptospermum scoparium had significantly more $(P=0.05)$ root mass $(>94 \%)$ confined within this radius than did the remainder of species, and for Myrsine australis and Knightia excelsa, 100\% of their total root mass remained confined within a 1-m radius. Beyond the $1-\mathrm{m}$ radius, the root mass of the remaining 10 of the trialled species decreased by an order of magnitude, and at the maximum radius of $2-2.5 \mathrm{~m}$, the root mass of Coriaria arborea, Sophora tetraptera, and Pittosporum eugenioides comprised $<0.5 \%$ of their respective total root mass. (Table 3).

There was no consistency in root biomass distribution by root diameter size class between the 11 heart-rooted species and one tap-rooted species studied. For example, fibrous roots $(<1 \mathrm{~mm})$ accounted for $\geq 30 \%$ of the total root biomass of the more compact of the heart-rooted Myrsine australis and Coprosma robusta and of the tap-rooted Cordyline australis but as little as $8 \%$ of the root mass of the heart-rooted Coriaria arborea (Table 4). Roots in the $>1$ to $<2-\mathrm{mm}$ diameter size class accounted for a significant proportion of the total root mass of the smaller root systems of Myrsine australis, Cordyline australis, and Knightia excelsa (range $12-19 \%)$ but for the larger of the heart-rooted species accounted for only $5-9 \%$. For all species, the bulk of the total root biomass was allocated to roots $>2 \mathrm{~mm}$ in diameter. With the exception of Myrsine australis and Cordyline australis, the largest-diameter roots $>20$ to < $50 \mathrm{~mm}$ were present in all the remaining heart-rooted species, comprising as little as $6-9 \%$ of the total root biomass of the compact Knightia excelsa, Coprosma robusta, and Leptospermum scoparium root systems but a higher proportion (range 14-25\%) of the larger root systems of the remaining heart-rooted species (Table 4).

Root biomass distribution by diameter size class and radial distance from the root bole showed that the largest-diameter roots $(20-50 \mathrm{~mm})$ were only present within a $0.5-\mathrm{m}$ radius of the root bole. At this radial distance, roots in this diameter size class comprised $21 \%$ of the total root mass of Coriaria arborea and Plagianthus regius but made up as little as $4 \%$ of one of the smallest root systems (Knightia excelsa) and were absent from the root systems of Myrsine australis and Cordyline australis. As the lateral roots branched and tapered to smaller diameters with increasing distance from the root bole, the proportion of total root mass allocated to each of the smaller root diameter sizes decreased rapidly. For only three species did the root mass extend beyond a 2 - $m$ radius where it consisted of fibrous roots and roots 
Table 2 Mean root bole and root biomass $(\mathrm{g})$ and as a percentage of total below-ground biomass by year 5

\begin{tabular}{|c|c|c|c|c|}
\hline \multirow[t]{2}{*}{ Species } & \multicolumn{2}{|l|}{ Root bole } & \multicolumn{2}{|l|}{ Roots } \\
\hline & Biomass & Percentage & Biomass & Percentage \\
\hline Coriaria arborea & $1017.5(373.9)^{b}$ & $36.0(1.8)^{b}$ & $1919.6(746.0)^{\mathrm{a}}$ & $64.0(1.8)^{d}$ \\
\hline Myrsine australis & $22.3(5.3)^{c}$ & $13.2(1.6)^{\mathrm{e}}$ & $134.4(22.1)^{c}$ & $86.8(1.6)^{\mathrm{a}}$ \\
\hline Pseudopanax arboreus & $117.6(37.4)^{c}$ & $24.1(2.1)^{\mathrm{cd}}$ & $350.2(107.0)^{c}$ & $75.9(2.1)^{b}$ \\
\hline Sophora tetraptera & $236.4(96.0)^{c}$ & $25.4(2.3)^{c d}$ & $623.3(174.9)^{\mathrm{bc}}$ & $74.6(2.3)^{b c}$ \\
\hline Cordyline australis & $2296.9(371.4)^{a}$ & $83.2(2.3)^{a}$ & $402.4(45.0)^{c}$ & $16.8(2.3)^{\mathrm{e}}$ \\
\hline Hoheria populnea & $403.3(108.6)^{c}$ & $31.3(2.3)^{\mathrm{bcd}}$ & $939.9(253.5)^{b c}$ & $68.7(2.3)^{\mathrm{cd}}$ \\
\hline Knightia excelsa & $97.8(17.1)^{c}$ & $31.7(1.8)^{\mathrm{bc}}$ & $214.0(40.1)^{c}$ & $68.3(1.8)^{c d}$ \\
\hline Pittosporum tenuifolium & $368.7(53.0)^{c}$ & $31.0(1.7)^{\mathrm{bcd}}$ & $847.7(111.9)^{\mathrm{bc}}$ & $69.0(1.7)^{c d}$ \\
\hline Pittosporum eugenioides & $348.5(24.1)^{c}$ & $23.4(1.5)^{d}$ & $1196.9(135.4)^{\mathrm{b}}$ & $76.6(1.5)^{b c}$ \\
\hline Coprosma robusta & $389.8(83.3)^{c}$ & $30.2(2.7)^{\mathrm{bcd}}$ & $928.0(184.0)^{\mathrm{bc}}$ & $69.8(2.7)^{\mathrm{cd}}$ \\
\hline Plagianthus regius & $660.7(97.2)^{\mathrm{bc}}$ & $38.9(3.0)^{b}$ & $1155.9(271.3)^{b}$ & $61.1(2.9)^{d}$ \\
\hline Leptospermum scoparium & $125.5(29.0)^{c}$ & $38.3(2.6)^{\mathrm{b}}$ & $193.6(37.3)^{c}$ & $61.7(2.6)^{d}$ \\
\hline
\end{tabular}

Values with different letters within each parameter were significantly different (Student-Newman-Keuls $P=0.05$ )

Table 3 Mean total root biomass $(\mathrm{g})$ and percentage of total root biomass by $0.5 \mathrm{~m}$ radial increment from the root bole by year 5

\begin{tabular}{|c|c|c|c|c|c|}
\hline Tree species & $0-0.5 \mathrm{~m}$ & $0.5-1.0 \mathrm{~m}$ & $1.0-1.5 \mathrm{~m}$ & $1.5-2.0 \mathrm{~m}$ & $2.0-2.5 \mathrm{~m}$ \\
\hline \multicolumn{6}{|l|}{ Root biomass } \\
\hline Coriaria arborea & $1227.3(468.5)^{a}$ & $484.9(213.9)^{\mathrm{a}}$ & $172.5(68.9)^{\mathrm{a}}$ & $34.1(17.8)^{a}$ & $1.0(1.0)^{\mathrm{a}}$ \\
\hline Myrsine australis & $127.4(21.3)^{\mathrm{e}}$ & $1.9(1.0)^{d}$ & - & - & - \\
\hline Pseudopanax arboreus & $291.2(82.2)^{\text {bcde }}$ & $54.4(22.5)^{c d}$ & $4.6(2.6)^{c}$ & - & - \\
\hline Sophora tetraptera & $406.4(112.0)^{\text {bcde }}$ & $150.9(41.8)^{\mathrm{bcd}}$ & $47.8(16.1)^{\mathrm{bc}}$ & $13.3(7.8)^{\mathrm{abc}}$ & $4.8(3.2)^{a}$ \\
\hline Cordyline australis & $240.2(36.4)^{\text {cde }}$ & $148.4(22.4)^{b c d}$ & $14.4(4.6)^{c}$ & $1.0(1.0)^{\mathrm{bc}}$ & - \\
\hline Hoheria populnea & $702.5(175.8)^{\mathrm{abcd}}$ & $196.4(66.0)^{b c d}$ & $36.0(13.5)^{\mathrm{bc}}$ & $5.0(2.0)^{b c}$ & - \\
\hline Knightia excelsa & $200.1(34.4)^{\mathrm{de}}$ & $13.9(6.5)^{c d}$ & - & - & - \\
\hline Pittosporum tennuifolium & $655.3(75.8)^{\mathrm{abcd}}$ & $158.7(34.2)^{\mathrm{bcd}}$ & $29.9(10.9)^{\mathrm{abc}}$ & $3.7(2.5)^{\mathrm{bc}}$ & - \\
\hline Pittosporum eugenioides & $730.6(81.3)^{\mathrm{bc}}$ & $322.0(49.9)^{b c}$ & $109.2(18.1)^{\mathrm{bc}}$ & $32.8(10.9)^{\mathrm{ab}}$ & $2.4(1.4)^{a}$ \\
\hline Coprosma robusta & $714.3(130.7)^{\mathrm{abc}}$ & $189.0(52.6)^{\mathrm{bcd}}$ & $24.3(7.8)^{\mathrm{ab}}$ & $0.3(0.3)^{b c}$ & - \\
\hline Plagianthus regius & $791.1(147.8)^{b}$ & $246.8(81.1)^{b c}$ & $97.1(40.5)^{\mathrm{abc}}$ & $20.9(8.0)^{\mathrm{abc}}$ & - \\
\hline Leptospermum scoparium & $179.4(32.6)^{\text {bcde }}$ & $12.8(6.3)^{\mathrm{cd}}$ & $1.3(1.3)^{\mathrm{bc}}$ & - & - \\
\hline \multicolumn{6}{|c|}{ Percentage of total root biomass } \\
\hline Coriaria arborea & $68.3(5.0)^{c}$ & $22.6(2.1)^{\mathrm{bc}}$ & $7.6(2.6)^{a}$ & $1.5(0.8)^{\mathrm{ab}}$ & $0.03(0.03)^{a}$ \\
\hline Myrsine australis & $99.0(0.4)^{a}$ & $1.0(0.4)^{\mathrm{e}}$ & - & - & - \\
\hline Pseudopanax arboreus & $87.4(2.7)^{\mathrm{b}}$ & $11.9(2.4)^{\mathrm{cd}}$ & $0.7(0.3)^{b}$ & - & - \\
\hline Sophora tetraptera & $68.6(3.6)^{c}$ & $23.9(2.4)^{b}$ & $7.2(1.4)^{\mathrm{a}}$ & $1.3(0.5)^{\mathrm{ab}}$ & $0.4(0.3)^{\mathrm{a}}$ \\
\hline Cordyline australis & $58.0(4.8)^{\mathrm{cd}}$ & $38.1(4.9)^{\mathrm{a}}$ & $3.7(1.4)^{b}$ & $0.2(0.2)^{b}$ & - \\
\hline Hoheria populnea & $79.4(3.4)^{b}$ & $16.7(2.6)^{\mathrm{bc}}$ & $3.1(0.7)^{b}$ & $0.7(0.5)^{b}$ & - \\
\hline Knightia excelsa & $95.4(1.6)^{\mathrm{a}}$ & $4.6(1.6)^{\mathrm{de}}$ & - & - & - \\
\hline Pittosporum tennuifolium & $79.1(2.9)^{b}$ & $17.7(2.0)^{\mathrm{bc}}$ & $2.9(0.9)^{b}$ & $0.3(0.2)^{b}$ & - \\
\hline Pittosporum eugenioides & $64.1(2.1)^{c}$ & $26.2(1.2)^{b}$ & $9.4(1.4)^{a}$ & $2.8(1.0)^{\mathrm{a}}$ & $0.2(0.1)^{\mathrm{a}}$ \\
\hline Coprosma robusta & $80.6(3.3)^{b}$ & $16.8(2.8)^{\mathrm{bc}}$ & $2.5(0.8)^{b}$ & $0.1(0.1)^{b}$ & - \\
\hline Plagianthus regius & $73.2(3.3)^{c}$ & $18.6(2.1)^{\mathrm{bc}}$ & $6.8(1.3)^{a}$ & $1.4(0.4)^{\mathrm{ab}}$ & - \\
\hline Leptospermum scoparium & $94.0(2.8)^{a}$ & $5.5(2.4)^{\mathrm{de}}$ & $0.5(0.5)^{b}$ & - & - \\
\hline
\end{tabular}


Table 4 Percent of mean total root biomass $(\mathrm{g})$ and root length $(\mathrm{m})$ by diameter size class at year 5

\begin{tabular}{|c|c|c|c|c|c|c|}
\hline \multicolumn{7}{|l|}{ Root diameter size class (mm) } \\
\hline Species & Fibrous $(<1)$ & $>1$ to $<2$ & $>2$ to $<5$ & $>5$ to $<10$ & $>10$ to $<20$ & $>20$ to $<50$ \\
\hline \multicolumn{7}{|l|}{ Root biomass } \\
\hline Coriaria arborea & 8 & 5 & 15 & 21 & 26 & 25 \\
\hline Myrsine australis & 30 & 19 & 25 & 18 & 8 & - \\
\hline Pseudopanax arboreus & 15 & 5 & 15 & 22 & 28 & 15 \\
\hline Sophora tetraptera & 15 & 9 & 18 & 18 & 21 & 19 \\
\hline Cordyline australis & 32 & 12 & 51 & 5 & - & - \\
\hline Hoheria populnea & 17 & 8 & 16 & 18 & 27 & 14 \\
\hline Knightia excelsa & 16 & 14 & 26 & 22 & 15 & 7 \\
\hline Pittosporum tenuifolium & 13 & 7 & 22 & 23 & 23 & 12 \\
\hline Pittosporum eugenioides & 10 & 8 & 23 & 23 & 21 & 15 \\
\hline Coprosma robusta & 34 & 7 & 18 & 19 & 13 & 9 \\
\hline Plagianthus regius & 16 & 6 & 14 & 18 & 21 & 25 \\
\hline Leptospermum scoparium & 13 & 6 & 21 & 28 & 26 & 6 \\
\hline \multicolumn{7}{|l|}{ Root length } \\
\hline Coriaria arborea & - & 46 & 37 & 12 & 4 & 1 \\
\hline Myrsine australis & - & 59 & 35 & 5 & 1 & - \\
\hline Pseudopanax arboreus & - & 44 & 37 & 14 & 4 & 1 \\
\hline Sophora tetraptera & - & 58 & 31 & 8 & 2.5 & 0.5 \\
\hline Cordyline australis & - & 38 & 59 & 3 & - & - \\
\hline Hoheria populnea & - & 57 & 32 & 7.5 & 3 & 0.5 \\
\hline Knightia excelsa & - & 61 & 32 & 5.5 & 1.5 & $<0.1$ \\
\hline Pittosporum tenuifolium & - & 43 & 44 & 10 & 2.5 & 0.5 \\
\hline Pittosporum eugenioides & - & 50.5 & 38 & 8.5 & 2.5 & 0.5 \\
\hline Coprosma robusta & - & 51 & 37 & 10 & 2 & $<0.1$ \\
\hline Plagianthus regius & - & 59 & 30 & 8 & 2 & 1 \\
\hline Leptospermum scoparium & - & 50 & 38 & 10 & 2 & $<0.1$ \\
\hline
\end{tabular}

$>1$ to $<5 \mathrm{~mm}$ diameter and comprised $<0.5 \%$ of their respective total plant root biomass.

The root system of Pittosporum eugenioides comprised the longest mean total root length of roots $>1 \mathrm{~mm}$ in diameter $(\sim 197 \mathrm{~m})$, which was not significantly different from that of either Plagianthus regius or Coriaria arborea but was significantly longer than for the remaining species $(P=0.05)$, particularly the fibrous-rooted Myrsine australis $(\sim 20.6 \mathrm{~m})$ (Table 1$)$. By year $5,>72 \%$ of the total root length occurred within $1.0 \mathrm{~m}$ of the root bole for all species, while only Coriaria arborea, Sophora tetraptera, and Pittosporum eugenioides developed roots beyond $2 \mathrm{~m}$, where they comprised $<0.6 \%$ of their mean total root length (Table 5).

Furthermore, the percentage of total root length decreased with increasing root size class. Roots in the $>1$ to $<2$-mm diameter size class made up the greatest proportion of the total root length for 10 of the trialled species (Table 4). The two exceptions were Cordyline australis and Pittosporum tenuifolium, which instead developed multiple lateral roots in the $>2$ to $<5-\mathrm{mm}$ diameter size class, comprising 59 and $44 \%$ of their respective total root length. For all species, the mean total root length of roots in the $>5-\mathrm{mm}$ size classes, as a proportion (\%) of total root length, was an order of magnitude less than for roots in the $>2$ to $<5$-mm diameter size class. Where present, the largest-diameter roots $(>20$ to $<50 \mathrm{~mm}$ ) comprised $<1 \%$ of the total root length of all the trialled species (Table 4).

The largest-diameter roots $(20-50 \mathrm{~mm})$, present only within a $0.5-\mathrm{m}$ radius of the root bole, comprised $<1 \%$ of the total root length of 10 of the species and were absent from the root systems of Myrsine australis and Cordyline australis. For all other root diameter size classes, the root length as a proportion of total root length decreased with increasing radial distance from the root bole. Only Coriaria arborea, Sophora tetraptera, and Pittosporum eugenioides had roots present beyond the 2 - $\mathrm{m}$ radius where they ranged in diameter from $>1$ to $<$ 
Table 5 Mean total root length $(\mathrm{m})$ and percentage of total root length by $0.5 \mathrm{~m}$ radial increment from the root bole by year 5

\begin{tabular}{|c|c|c|c|c|c|}
\hline Tree species & $0-0.5 \mathrm{~m}$ & $0.5-1.0 \mathrm{~m}$ & $1.0-1.5 \mathrm{~m}$ & $1.5-2.0 \mathrm{~m}$ & $2.0-2.5 \mathrm{~m}$ \\
\hline \multicolumn{6}{|l|}{ Root length } \\
\hline Coriaria arborea & $55.0(13.0)^{\mathrm{a}}$ & $61.2(18.0)^{\mathrm{ab}}$ & $31.9(11.7)^{\mathrm{abc}}$ & $17.0(5.5)^{\mathrm{a}}$ & $0.8(0.8)^{a}$ \\
\hline Myrsine australis & $19.4(2.6)^{b}$ & $1.2(0.7)^{c}$ & - & - & - \\
\hline Pseudopanax arboreus & $24.1(5.2)^{b}$ & $13.7(6.6)^{\mathrm{bc}}$ & $2.5(1.4)^{c}$ & - & - \\
\hline Sophora tetraptera & $29.3(3.5)^{b}$ & $30.1(7.1)^{\mathrm{bc}}$ & $14.7(4.1)^{\mathrm{abc}}$ & $4.6(2.3)^{b}$ & $0.9(0.7)^{a}$ \\
\hline Cordyline australis & $64.6(8.9)^{\mathrm{a}}$ & $31.7(4.1)^{\mathrm{bc}}$ & $4.7(1.5)^{c}$ & $0.3(0.3)^{b}$ & - \\
\hline Hoheria populnea & $79.8(9.9)^{a}$ & $37.5(13.6)^{\mathrm{bc}}$ & $10.5(3.2)^{\mathrm{abc}}$ & $3.2(1.4)^{b}$ & - \\
\hline Knightia excelsa & $39.9(6.7)^{\mathrm{a}}$ & $6.4(2.7)^{c}$ & - & - & - \\
\hline Pittosporum tennuifolium & $67.5(5.4)^{\mathrm{a}}$ & $37.4(6.9)^{b c}$ & $12.1(3.9)^{\mathrm{abc}}$ & $1.7(0.9)^{b}$ & - \\
\hline Pittosporum eugenioides & $66.1(6.4)^{\mathrm{a}}$ & $81.2(14.8)^{a}$ & $35.9(4.1)^{a}$ & $13.1(3.8)^{\mathrm{a}}$ & $1.0(0.6)^{a}$ \\
\hline Coprosma robusta & $67.0(10.0)^{\mathrm{a}}$ & $29.9(8.3)^{b c}$ & $6.5(2.3)^{\mathrm{bc}}$ & $0.1(0.1)^{b}$ & - \\
\hline Plaganthus regius & $71.1(11.2)^{\mathrm{a}}$ & $46.8(12.0)^{\mathrm{b}}$ & $32.9(16.1)^{\mathrm{ab}}$ & $8.8(3.4)^{\mathrm{ab}}$ & - \\
\hline Leptospermum scoparium & $18.8(2.0)^{\mathrm{b}}$ & $5.6(2.3)^{b c}$ & $1.1(1.0)^{\mathrm{abc}}$ & - & - \\
\hline \multicolumn{6}{|l|}{ Percentage of total root length } \\
\hline Coriaria arborea & $40.0(6.2)^{\mathrm{efg}}$ & $38.6(1.9)^{\mathrm{a}}$ & $16.4(4.7)^{\mathrm{a}}$ & $4.8(2.5)^{\mathrm{ab}}$ & $0.2(0.2)^{a}$ \\
\hline Myrsine australis & $96.0(1.8)^{\mathrm{a}}$ & $4.0(1.8)^{c}$ & - & - & - \\
\hline Pseudopanax arboreus & $72.4(6.2)^{\mathrm{bc}}$ & $24.4(2.8)^{b}$ & $3.1(1.6)^{b}$ & - & - \\
\hline Sophora tetraptera & $43.2(4.8)^{\mathrm{fg}}$ & $35.8(2.8)^{a}$ & $16.6(2.3)^{\mathrm{a}}$ & $3.7(1.3)^{\mathrm{ab}}$ & $0.6(0.4)^{a}$ \\
\hline Cordyline australis & $62.4(8.9)^{\text {cde }}$ & $32.7(4.1)^{\mathrm{a}}$ & $4.7(1.8)^{b}$ & $0.2(0.2)^{b}$ & - \\
\hline Hoheria populnea & $60.9(6.3)^{\text {cdef }}$ & $28.6(4.4)^{\mathrm{a}}$ & $8.0(1.8)^{b}$ & $2.4(1.4)^{\mathrm{ab}}$ & - \\
\hline Knightia excelsa & $88.0(4.1)^{\mathrm{ab}}$ & $12.0(4.1)^{\mathrm{C}}$ & - & - & - \\
\hline Pittosporum tennuifolium & $56.9(5.7)^{\text {cdef }}$ & $28.6(2.8)^{a}$ & $10.1(2.4)^{b}$ & $1.5(0.6)^{b}$ & - \\
\hline Pittosporum eugenioides & $35.0(3.5)^{9}$ & $38.4(3.5)^{\mathrm{a}}$ & $18.8(2.1)^{\mathrm{a}}$ & $7.3(2.52)^{\mathrm{a}}$ & $0.5(0.3)^{a}$ \\
\hline Coprosma robusta & $68.5(5.9)^{c d}$ & $24.7(4.2)^{\mathrm{b}}$ & $6.6(2.9)^{b}$ & $0.1(0.1)^{b}$ & - \\
\hline Plagianthus regius & $50.7(4.0)^{\text {defg }}$ & $28.6(1.9)^{\mathrm{a}}$ & $15.8(2.8)^{\mathrm{a}}$ & $4.9(1.4)^{\mathrm{ab}}$ & - \\
\hline Leptospermum scoparium & $77.9(7.6)^{\mathrm{abc}}$ & $19.5(6.3)^{b}$ & $2.6(2.3)^{b}$ & - & - \\
\hline
\end{tabular}

In years 1-2, for each species, all the root mass was confined to within a 0-0.5-m radius of the root bole. Values in parentheses are representative of the standard error of the mean. Values with a different letter and within each radial segment were significantly different (Student-Newman-Keuls $P=0.05$ )

$10 \mathrm{~mm}$ and collectively accounted for $<1 \%$ of their respective total root lengths.

The root systems of all the trialled species remained confined to within $0.5 \mathrm{~m}$ of the ground surface. The roots of Myrsine australis reached a mean maximum root depth of $0.21 \mathrm{~m}$ and was the shallowest, and although not significantly different from most of the remaining heart-rooted species, it was significantly shallower $(P=0.05)$ than that of the deeper tap-rooted Cordyline australis $(0.45 \mathrm{~m})$ (Table 1).

\section{Allometric relationships}

Exponential regression analysis of RCD and mean total BGB data for Knightea excelsa produced a poor fit $\left(r^{2}=\right.$ 0.67), but a good fit was obtained for the remainder of species, including Leptospermum scoparium $\left(r^{2}=0.94\right)$. All regressions were highly significant $(P<0.001$, Fig. 3$)$.

Exponential regressions of RCD and total root biomass for the $>1$ and $>2-\mathrm{mm}$ diameter size classes were similar, and for all 12 species, RCD explained $>49 \%$ of the variation in root biomass for roots in the $>1-\mathrm{mm}$ size class and $>31 \%$ of the variation for roots in the $>$ 2-mm diameter size class (Table 6, Fig. 4). Regressions for total root length against RCD were a better fit, with RCD explaining $>63 \%$ of the variation in root length for roots $>1 \mathrm{~mm}$ and $>55 \%$ for roots $>2 \mathrm{~mm}$ (Table 6 , Fig. 5).

\section{Discussion}

Root architecture

Published accounts on the architecture of root systems of New Zealand's riparian and early colonising species are rare and largely descriptive (Watson and O'Loughlin 1985; Marden et al. 2005). At the time of establishing this trial, few pieces of data (measurements, photographic or descriptive) were available on the architecture and root metrics of the trialled species. 

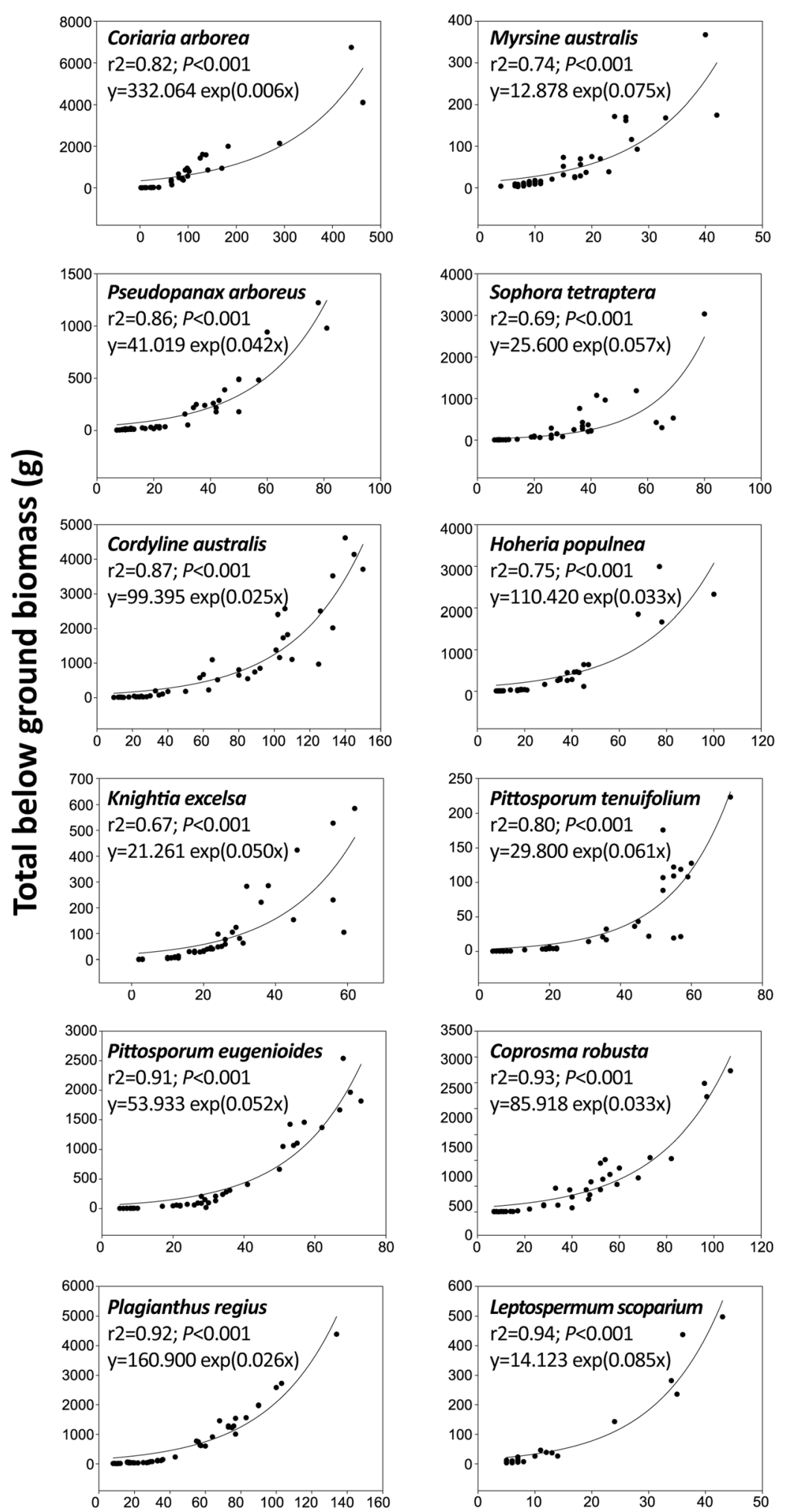

\section{Root collar diameter ( $\mathrm{mm}$ )}

Fig. 3 Exponential growth analysis of RCD and total below-ground biomass 
Table 6 Regression analyses for RCD against total root length and biomass for roots $>1$ and $>2$ mm diameter

\begin{tabular}{|c|c|c|c|c|c|c|c|}
\hline \multirow[t]{2}{*}{ Species } & \multirow{2}{*}{$\begin{array}{l}\text { Root size } \\
\text { class }\end{array}$} & \multicolumn{3}{|c|}{ Root length } & \multicolumn{3}{|c|}{ Root biomass } \\
\hline & & $\overline{r^{2}}$ & $P$ & Equation & $\overline{r^{2}}$ & $P$ & Equation \\
\hline \multirow[t]{2}{*}{ Coriaria arborea } & $>1 \mathrm{~mm}$ & 0.918 & $<0.001$ & $y=0.567 x-0.897$ & 0.806 & $<0.001$ & $y=226.783 \exp (0.006 x)$ \\
\hline & $>2 \mathrm{~mm}$ & 0.896 & $<0.001$ & $y=0.309 x-0.468$ & 0.807 & $<0.001$ & $y=189.657 \exp (0.006 x)$ \\
\hline \multirow[t]{2}{*}{ Myrsine australis } & $>1 \mathrm{~mm}$ & 0.801 & $<0.001$ & $y=0.880 x-6.678$ & 0.705 & $<0.001$ & $y=11.959 \exp (0.073 x)$ \\
\hline & $>2 \mathrm{~mm}$ & 0.803 & $<0.001$ & $y=0.373 x-2.778$ & 0.712 & $<0.001$ & $y=5.121 \exp (0.077 x)$ \\
\hline \multirow[t]{2}{*}{ Pseudopanax arboreus } & $>1 \mathrm{~mm}$ & 0.788 & $<0.001$ & $y=1.049 x-12.900$ & 0.825 & $<0.001$ & $y=31.135 \exp (0.042 x)$ \\
\hline & $>2 \mathrm{~mm}$ & 0.782 & $<0.001$ & $y=0.590 x-7.732$ & 0.812 & $<0.001$ & $y=22.349 \exp (0.044 x)$ \\
\hline \multirow[t]{2}{*}{ Sophora tetraptera } & $>1 \mathrm{~mm}$ & 0.633 & $<0.001$ & $y=1.623 x-13.699$ & 0.652 & $<0.001$ & $y=29.755 \exp (0.050 x)$ \\
\hline & $>2 \mathrm{~mm}$ & 0.664 & $<0.001$ & $y=0.723 x-6.792$ & 0.685 & $<0.001$ & $y=17.419 \exp (0.054 x)$ \\
\hline \multirow[t]{2}{*}{ Cordyline australis } & $>1 \mathrm{~mm}$ & 0.828 & $<0.001$ & $y=0.909 x-13.407$ & 0.486 & $<0.001$ & $y=80.922 \exp (0.014 x)$ \\
\hline & $>2 \mathrm{~mm}$ & 0.744 & $<0.001$ & $y=0.587 x-10.748$ & 0.313 & $<0.001$ & $y=67.463 \exp (0.012 x)$ \\
\hline \multirow[t]{2}{*}{ Hoheria populnea } & $>1 \mathrm{~mm}$ & 0.799 & $<0.001$ & $y=1.915 x-22.421$ & 0.749 & $<0.001$ & $y=77.360 \exp (0.033 x)$ \\
\hline & $>2 \mathrm{~mm}$ & 0.981 & $<0.001$ & $y=0.426 x-0.113$ & 0.681 & $<0.001$ & $y=61.306 \exp (0.032 x)$ \\
\hline \multirow[t]{2}{*}{ Knightia excelsa } & $>1 \mathrm{~mm}$ & 0.676 & $<0.001$ & $y=1.014 x-8.843$ & 0.669 & $<0.001$ & $y=13.747 \exp (0.051 x)$ \\
\hline & $>2 \mathrm{~mm}$ & 0.546 & $<0.001$ & $y=0.387 x-3.275$ & 0.630 & $<0.001$ & $y=6.967 \exp (0.057 x)$ \\
\hline \multirow[t]{2}{*}{ Pittosporum tenuifolium } & $>1 \mathrm{~mm}$ & 0.796 & $<0.001$ & $y=2.229 x-21.396$ & 0.760 & $<0.001$ & $y=25.055 \exp (0.058 x)$ \\
\hline & $>2 \mathrm{~mm}$ & 0.764 & $<0.001$ & $y=1.241 x-12.923$ & 0.742 & $<0.001$ & $y=18.090 \exp (0.060 x)$ \\
\hline \multirow[t]{2}{*}{ Pittosporum eugenoides } & $>1 \mathrm{~mm}$ & 0.817 & $<0.001$ & $y=3.536 x-42.563$ & 0.903 & $<0.001$ & $y=37.578 \exp (0.054 x)$ \\
\hline & $>2 \mathrm{~mm}$ & 0.777 & $<0.001$ & $y=19.22 x-24.495$ & 0.885 & $<0.001$ & $y=30.161 \exp (0.054 x)$ \\
\hline \multirow[t]{2}{*}{ Coprosma robusta } & $>1 \mathrm{~mm}$ & 0.785 & $<0.001$ & $y=1.546 x-18.772$ & 0.918 & $<0.001$ & $y=62.745 \exp (0.033 x)$ \\
\hline & $>2 \mathrm{~mm}$ & 0.805 & $<0.001$ & $y=0.802 x-11.295$ & 0.906 & $<0.001$ & $y=23.155 \exp (0.038 x)$ \\
\hline \multirow[t]{2}{*}{ Plagianthus regius } & $>1 \mathrm{~mm}$ & 0.711 & $<0.001$ & $y=2.191 x-44.685$ & 0.942 & $<0.001$ & $y=86.829 \exp (0.080 x)$ \\
\hline & $>2 \mathrm{~mm}$ & 0.840 & $<0.001$ & $y=0.415 x-18.021$ & 0.917 & $<0.001$ & $y=71.572 \operatorname{eexp}(0.027 x)$ \\
\hline \multirow[t]{2}{*}{ Leptospermum scoparium } & $>1 \mathrm{~mm}$ & 0.842 & $<0.001$ & $y=0.832 x-3.672$ & 0.935 & $<0.001$ & $y=10.598 \exp (0.080 x)$ \\
\hline & $>2 \mathrm{~mm}$ & 0.858 & $<0.001$ & $y=0.441 x-2.603$ & 0.971 & $<0.001$ & $y=5.174 \exp (0.093 x)$ \\
\hline
\end{tabular}

The root systems of the majority of the trialled heart-rooted species developed a high proportion of vertical and obliquely inclined, structural-size roots (> $1 \mathrm{~mm}$ diameter), which struck horizontally at a relatively shallow depth and changed orientation frequently. The development of a heart-shaped root architecture prevents the roots from penetrating deeper and may indeed be an adaptation typical of early colonising species in their search for nutrients and surface water and to provide a higher level of near-surface soil reinforcement and stability (wind firmness) at a greater distance from the stem. In the absence of any observable differences in the physical attributes of the soil at the trial site, Marden et al. (2018, in press) considered it is more likely that interspecies differences in the distribution of roots and their overall root system architecture are inherent rather than due to competing influences from adjacent well-spaced plants, seedling propagation, or planting practices.

Clearly, some species consistently outperformed others in terms of the metrics important for soil-root reinforcement (e.g. root system diameter, total BGB and root length, root depth) and are clear contenders for planting on marginal land for the primary purpose of mitigating erosion. Based solely on a comparison of the relative differences in root system dimensions, the tap-rooted Cordyline australis and the heart-rooted Pittosporum tenuifolium, Pittosporum eugenioides, Plagianthus regius, Sophora tetraptera, Coriaria arborea, and Hoheria populnea adapted to the site conditions earliest, developed the largest root systems, and will, therefore, likely provide a higher level of soil-root reinforcement than will the slowest growing of the species with smaller root systems. Phillips et al. (2015) similarly compared differences in root system dimensions among exotic species, including alder (Alnus rubra), cypress (Cupressus lucitanica), and blackwood (Acacia melanoxylon), with reported values for indigenous riparian species (Marden et al. 2005), mānuka (Marden and Lambie 2016) and Pinus radiata at a similar age (Watson and Tombleson 2002, 2004; Marden et al. 2016). They concluded that the species that developed 

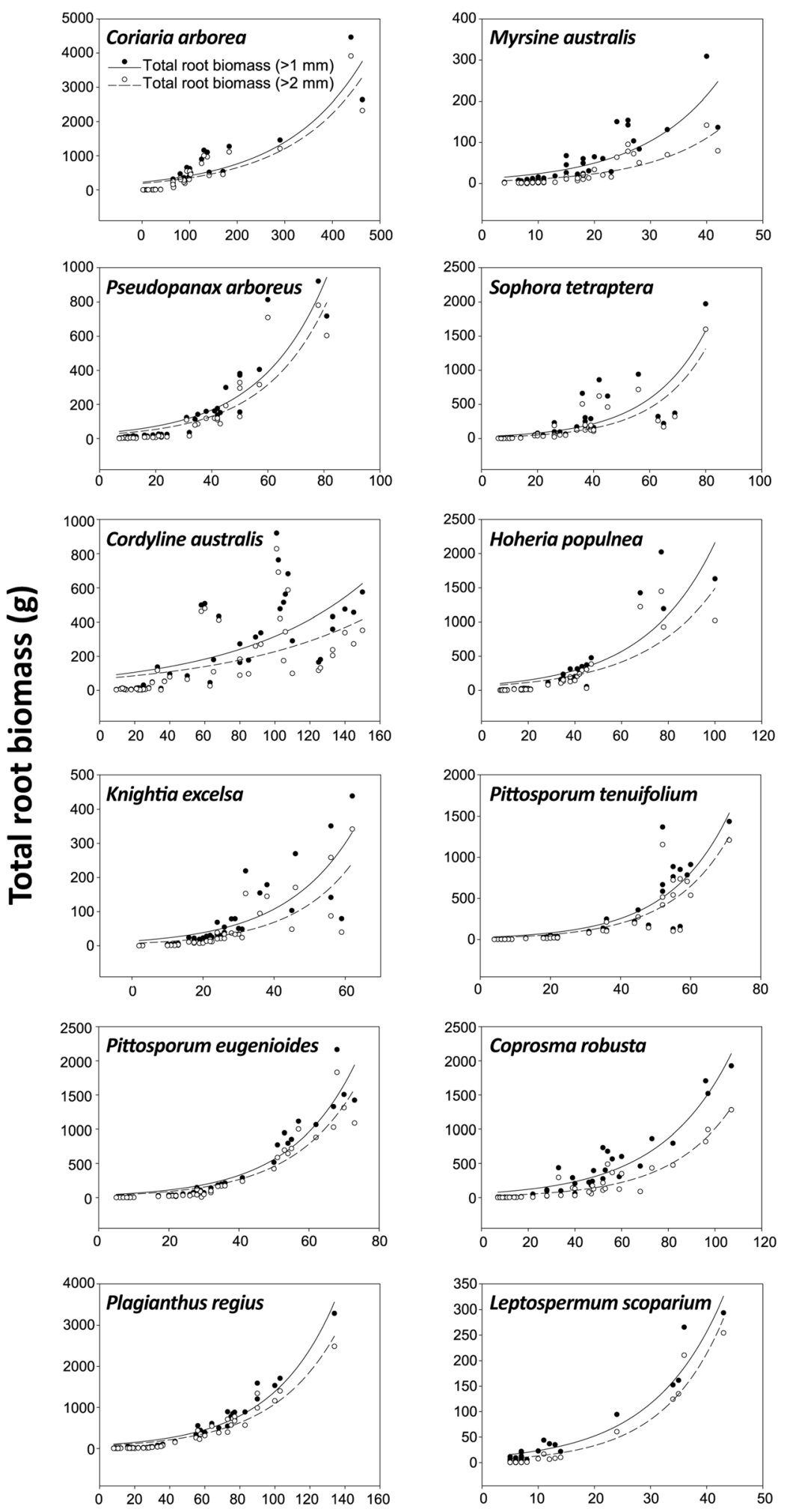

\section{Root collar diameter $(\mathrm{mm})$}

Fig. 4 Exponential growth analysis of RCD and total root biomass for roots $>1 \mathrm{~mm}$ (black circle) and $>2 \mathrm{~mm}$ (white circle) diameter. Regression equations are presented in Table 6 

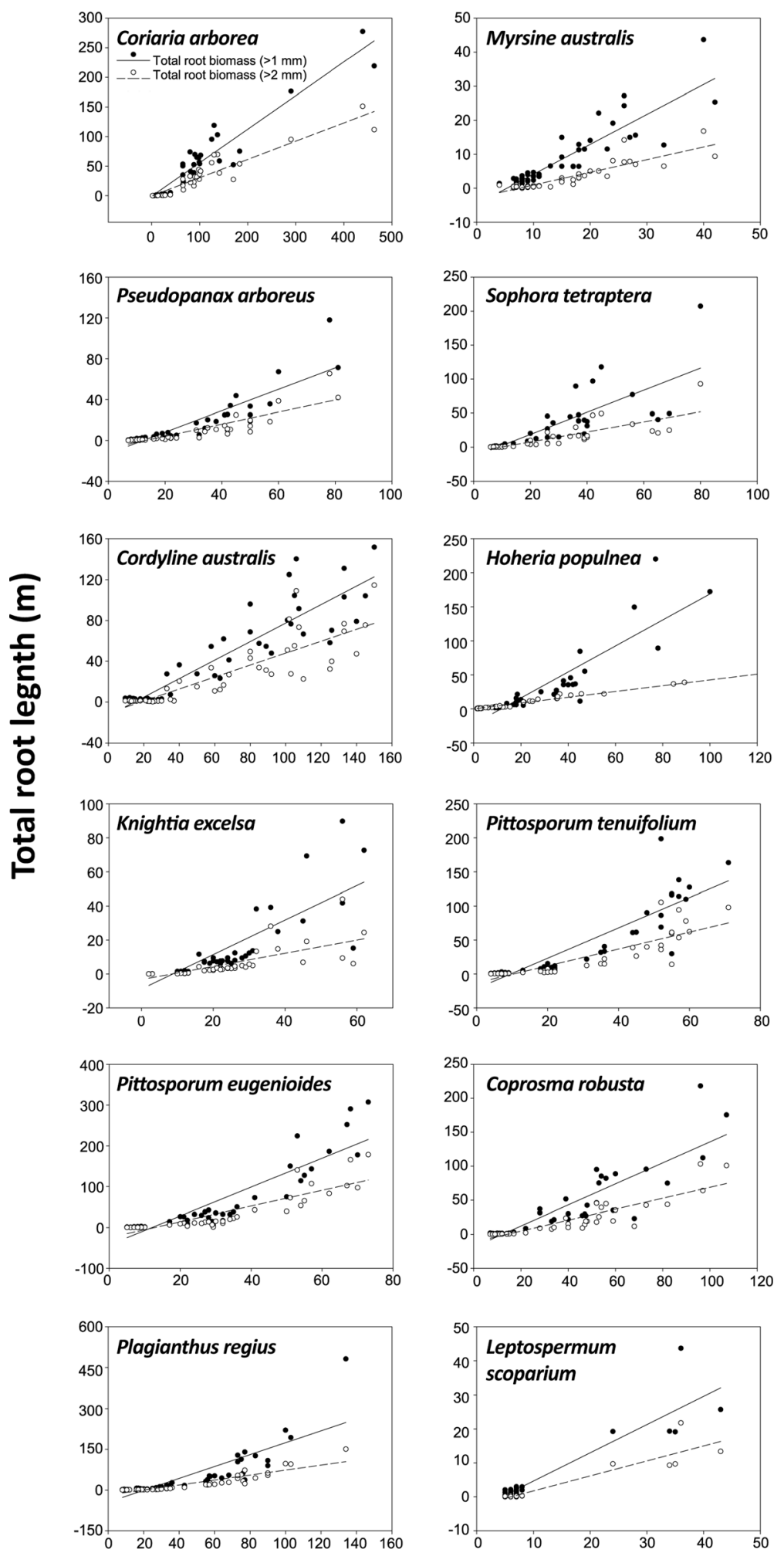

\section{Root collar diameter $(\mathrm{mm})$}

Fig. $\mathbf{5}$ Linear analysis of RCD and total root length for roots $>1 \mathrm{~mm}$ (black circle) and $>2 \mathrm{~mm}$ (white circle) diameter. Regression equations are presented in Table 6 
large root system dimensions would provide earlier soil-root reinforcement and thus be more effective at mitigating the initiation of shallow landslides.

\section{Root biomass and length distribution}

Several New Zealand and international studies have shown that root systems of old-growth exotic and indigenous shrubland/forest species comprise approximately $20 \%$ of the total live tree biomass (Watson and Tombleson 2002; Beets et al. 2007). The precision of these root estimates tends to be low (Hall et al. 2001), but, nonetheless, they have been used in the absence of more reliable species-specific data. However, less is known about New Zealand's most common indigenous species such as how much of the total biomass is allocated to the root systems (roots plus root bole combined) during their early growth period. This ranged between 24 and $44 \%$ by year 5 for the species trialled here. The root:shoot ratio also decreased with increasing age, which was consistent with early results obtained by Marden et al. (2005). The current results are not dissimilar to values for six similar-aged indigenous conifers $(\sim 23 \%)$ and two broadleaved species $(\sim 41 \%)$ (Marden et al. 2018, in press) or to values for 3-year-old exotic species including Eucalyptus fastigata (33\%), Sequoia sempervirens (29\%), Acacia melanoxylon (37\%), and Pinus radiata (36\%) trialled at the same site (Phillips et al. 2015). While the BGB for each of five different 5-year-old clones of Pinus radiata $(\sim 22 \%)$ planted in a steep hill country location (Marden et al. 2016) was at the lower end of this range, it is nonetheless consistent with that for similar-aged pines planted at a range of New Zealand field locations (Watson and Tombleson 2002, 2004). These results likely reflect the harsher edaphic and climatic factors (Ketterings et al. 2001) at these field locations than at the trial site.

Less well-documented for New Zealand's most common indigenous species is the variability in the proportion of $\mathrm{BGB}$ apportioned to the roots versus the root bole of different root system types (e.g. tap- versus heart-rooted). As an example, the tap-rooted species Cordyline australis (the deepest-rooted of the trialled species) allocated more than $80 \%$ of total BGB to the root bole and $<20 \%$ to its roots (cf $>61 \%$ for heart-rooted species), and this difference was significant $(P=0.05)$. Furthermore, the allocation of root biomass to the different root size classes differed among species. For example, the root systems of Myrsine australis, Cordyline australis, and Coprosma robusta were dominated by fibrous roots comprising $\geq 30 \%$ of their total root biomass. Conversely, fibrous roots may comprise as little as $8 \%$ of the total root mass in species with root systems dominated by unevenly distributed structural roots (> $1 \mathrm{~mm}$ diameter). Furthermore, $>73 \%$ of the mean total length of roots $>1 \mathrm{~mm}$ in diameter and $>90 \%$ of the total root mass occurred within $1.0 \mathrm{~m}$ of the root bole for all species irrespective of the significant differences in root system dimensions of different species. Additionally, the coarsest roots occurred closest to the root bole. As might be expected, root systems comprising the largest mass, length, and diameter sizes form a dense membrane (Schmidt et al. 2001) that provides a higher level of soil-root reinforcement (Swanston and Swanson 1976) closest to the root bole. These traits were also observed during the excavation of root systems of other indigenous species that developed similarly compact, dense root systems, including the conifers Prumnopitys taxifolia and Prumnopitys ferruginea, the broadleaved Alectryon excelsa (Marden et al. 2018, in press), and the exotic species Quercus robur and Sequoia sempervirens (Phillips et al. 2015). However, as is common to all species, the level of soil-root reinforcement rapidly decreases as the density of roots tapers off with increasing distance from the root bole.

The mechanical interactions of woody roots with the soil medium also play an important role in tree anchorage. Therefore, one of the most important traits of a root system is rooting depth, which is species-dependent when soil conditions are not limiting. In New Zealand, the most common form of erosion occurs from landslides initiated by storms. Such landslides are typically small, shallow, and translational, with failure often coinciding with a basal shear plane $\leq 1 \mathrm{~m}$ depth (Marden et al. 1991; Page et al. 1994). Thus, roots must cross the basal shear plane (Wu et al. 1979) in order to anchor the soil into more stable substrate and stabilise a slope against the initiation of shallow landslides. The entire root system of each of the trialled species was confined to the upper $0.5 \mathrm{~m}$ of the soil profile, but this is typical for many other juvenile indigenous species at a similar age (Watson et al. 1995; Marden et al. 2005; Marden et al. 2018 in press). The absence of larger roots with the potential to provide reinforcement across the basal shear plane (Clark et al. 2008) suggests that new plantings of these species are unlikely to prevent the occurrence of shallow slope failure within 5 years of planting. Despite this, Watson and O'Loughlin (1985) noted that the root systems of older and more mature Leptospermum scoparium extended to a depth of $0.5 \mathrm{~m}$ on stony soils and $0.8 \mathrm{~m}$ on sandy soils. Additionally, the root systems of individual Kunzia ericoides, a closely related early colonising species, can extend to a maximum depth of between 1.5 and $2.2 \mathrm{~m}$ (Watson et al. 1995), and the roots of Cordyline australis have been found to extend to a depth of $2 \mathrm{~m}$ (Czernin and Phillips 2005). There are no known reports of the rooting depth of mature specimens of the remaining of the trialled species. However, observations of storm-related landslide damage associated with areas of naturally reverted stands comprising these shrubland species suggest that it is highly likely that in sufficient numbers, and given time to mature, they will 
provide sufficient anchorage to at least moderate the incidence of storm-initiated shallow landslides.

\section{Regression analyses of root biomass and length}

Wagner and Ter-Mikaelian (1999) suggested that RCD may serve as a better predictor of both aboveand below-ground biomass as stem taper in seedlings is minimal. The allometric biomass equations presented in this paper indicate that there are clear differences in root growth performance among species, at least at their juvenile stage, and that different fitted coefficients are required. Although comparisons with published work on root growth performance of other juvenile New Zealand indigenous species are limited, RCD was found to be a good fit for estimating total root biomass and root length with regressions being highly significant $(P<0.001)$. Marden et al. $(2018$ in press) also found RCD to be a good fit for estimating these relationships for eight of New Zealand's indigenous conifer and broadleaved species, with each species requiring a specific fitted coefficient. Similarly, Phillips et al. (2015) found it possible to develop simple relationships between RCD and the growth attributes of a variety of exotic forest species grown in New Zealand, with reasonable $r^{2}$ values for BGB and total root length. Furthermore, Marden et al. (2016) found that two-parameter exponential regressions using RCD were successful in predicting the BGB of five seed lots of Pinus radiata between 1 and 4 years old with RCD explaining between 93 and $98 \%$ of the variability in BGB.

Regressions between RCD and root biomass showed there were no differences between the slopes of the regression curves $(P=0.867)$ for roots $>1 \mathrm{~mm}$ in diameter compared with roots $>2 \mathrm{~mm}$ in diameter. This regression explained between 49 and $94 \%$ of the variation in root biomass for roots in the $>1-\mathrm{mm}$ diameter size class and between 31 and $97 \%$ of the variation for roots in the $>2$-mm diameter size class. Conversely, regressions for total root length found that the slope of the regression curves for roots $>1 \mathrm{~mm}$ in diameter was significantly greater $(P=0.006)$ than the slope of the curve for roots $>2 \mathrm{~mm}$ in diameter. That is, regressions for total root length against RCD were a better fit than the regressions for biomass and explained between 63 and $91 \%$ of the variation in root length for roots $>1 \mathrm{~mm}$ diameter and between 55 and $98 \%$ for roots $>2 \mathrm{~mm}$ diameter. This indicates that the increase in root length of the 1-2-mm diameter size class is greater than for the other root diameter size classes as RCD increases. Thus, any linear regression analyses using $\mathrm{RCD}$ against root length that excludes roots in the 1-2-mm diameter size class would not represent the change in apportionment of total root length by root diameter size with increasing age.

\section{Potential use of trialled species for erosion control}

Although the selection of trialled species is small, it does include some of the most common and widely distributed of New Zealand's indigenous seral species. Also, although the length of the trial was limited to 5 years, the information from this study has provided valuable insights on inter-species differences in their root metrics (i.e. root system dimensions, root mass and length, and root depth). Such information is of value in assessing their potential mechanical influences on slope stability, for example, during a period of transition from marginal pastoral land to a more permanent woody vegetation cover and/or when converting areas of exotic forest with a 'high erosion risk' to indigenous shrubland. Additionally, the role of native seral shrubland species as a nursery for successional hardwood species meets most of the requirements where long-term erosion control is required (Pollock 1986) even though they have not traditionally been used specifically for soil conservation.

The results from this trial suggest that species selection and mix, planting density, and age of plantings are key factors in ensuring a successful erosion mitigation outcome for areas of land identified as erosion-prone and marginal for pastoral production but ideally suited for conversion to indigenous shrubland. Options that promote full soil-root reinforcement the quickest are likely to be the most effective in enhancing slope stability (Phillips et al. 2001). The mechanical reinforcement of soil by roots (Watson et al. 1999) improves land stability, but it is also the means by which trees extract moisture from the soil to reduce pore-water pressures (Ekanayake et al. 1997). However, the role of the tree canopy through the processes of interception (Kelliher et al. 1992) and transpiration (Pearce et al. 1987) also plays a significant role in lessening the initiation of shallow slope failures. It is clear from the published literature that a relationship exists between rainfall intensity/duration, landslide density, and vegetation type and maturity (Selby 1976, Salter et al. 1983) even though the magnitude of interception loss as a percentage of rainfall during extreme rainfall events is small (Blake 1965; Rowe et al. 1999; Aldridge and Jackson 1968, 1973; Jackson and Aldridge 1973). Indeed, the occurrence of landslides initiated during a major storm (Cyclone Bola in 1988) was considerably less in areas of well-established naturally regenerating shrubland and indigenous forest compared to adjacent pastoral hill country, and damage was greatest in areas that received the most rainfall (Marden et al. 1995). Furthermore, while seral vegetation during the initial years after establishment would afford little protection against the initiation of landslides in the event of a major storm, the reduction in storm-initiated slope failures was shown to be significant once canopy closure had been attained (Marden and Rowan 1993). Thus, the 
combined benefits of soil-root reinforcement and hydrological influences become most effective when full root occupancy (lateral roots of adjacent trees overlap) and canopy closure (crowns of individual trees touch) first occur (Kelliher et al. 1992).

For each of the trialled species, and in each year of the trial, the mean maximum spread of their root systems exceeded crown width (data not shown). By year 5, the root system diameter of Sophora tetraptera, Plagianthus regius, Pittosporum tenuifolium, Hoheria populnea, and Pittosporum eugenioides was approximately twice that of their respective crown widths; thus, root reinforcement of the soil was well-advanced by the time canopy closure had occurred. Notwithstanding, species with wide crowns consisting of dense foliage (e.g. Coriaria arborea and Coprosma robusta) likely provide earlier hydrological and root-reinforcement benefits than the taller and more upright species with compact, narrow crowns (e.g. Cordyline australis, Pittosporum tenuifolium, Pittosporum eugenioides, Hoheria populnea, Pseudopanax arboreus, Plagianthus regius) and smaller-diameter root systems (e.g. Myrsine australis, Knightea excelsa, and Leptospermum scoparium).

Irrespective of plant species, juvenile plantings are clearly vulnerable to storm influences until such time as soil-root reinforcement is sufficiently advanced to prevent the initiation of shallow landslides and to a lesser extent the deeper-seated types of slope failure. The duration of this period of vulnerability is at least in part influenced by plant growth rates, species mix, and planting density. While there is an expectation that a mix of the fastest growing species planted at a high density will shorten the duration of this period of vulnerability, there is little data with which to establish how long (i.e. years after plant establishment) it might take for different planting density strategies, and species mixes, to afford protection against the initiation of shallow landslides. Time-series accounts of the growth rates of juvenile indigenous shrub and tree species are scarce, as are planting guidelines for establishing seral indigenous species on erosion-prone pastoral hill country. Furthermore, there are no known accounts of the growth rates, species mix, or density of seral indigenous species likely to proliferate on retired farmland or on areas of exotic forest clear-felled but not replanted. Thus, the duration of the period of vulnerability during which slopes passively transition from one vegetation type to another, and are at greatest risk to damaging storm events, is uncertain.

Industry-led planting density recommendations for mānuka, established on steep hillsides at between 1100 and 1600 stems $\mathrm{ha}^{-1}$, and primarily for honey production, have an expectation that, in time, such plantings will provide protection against the initiation of shallow landslides. In a field trial established to measure the above- and below-ground growth performance of mānuka planted on steep hill country at 1100 stems ha ${ }^{-1}$ ( $3 \mathrm{~m} \times 3 \mathrm{~m}$ spacing), Marden and Lambie (2016) were able to demonstrate that the lateral roots of mānuka extended radially from the root bole at a rate similar to that of individual trees of the same age extracted from a denser stand of naturally reverted kānuka, thereby suggesting that the root systems of adjacent plants within a planted stand of mānuka would likely overlap within 4.5 years of establishment. However, the stem density in a planted stand of mānuka is at least an order of magnitude less than is typically found in a fully stocked stand of naturally reverting shrubland so the root mass in the planted stand would also be less dense. Taking this factor into account, the authors concluded that stands of planted mānuka would likely remain vulnerable to storm-initiated landslides for longer than a naturally reverting stand and estimated that the period of vulnerability for plantings on the most productive sites would be at least 7 to 8 years after establishment and even longer on the harsher and less productive sites. Indeed, historical evidence documenting the occurrence of storm-initiated landslides within stands of naturally reverting shrubland of known age and density showed that a fully stocked stand of 8-year-old shrubland dominated by kānuka afforded a $54 \%$ reduction in storm-initiated landslides and a 16-year-old stand afforded a 91\% reduction relative to that which occurred on adjacent areas of pastoral land. Furthermore, Ekanayake et al. (1997) were able to demonstrate that by increasing the stand density to 2000 stems ha ${ }^{-1}$, which is twice the density recommended for mānuka plantings, the stability of planted slopes would not likely improve until the plantings were at least 8 years old. Unfortunately, due to the recentness of the planting of significant areas of wide-spaced plantings of mānuka, and in the absence of any significant storm events, the age (years after planting) at which such plantings improve slope stability and their effectiveness in mitigating shallow landslides has yet to be substantiated.

Based on the annual growth increments of the lateral roots of the 12 species trialled, all but three had developed roots beyond a $1.5-\mathrm{m}$ radius of the root bole (i.e. half the distance between adjacent trees) by age 5 years (Fig. 6). However, the mass and length of roots present at this distance by year 5 was minimal even for the best performed Pittosporum eugenioides. For the species with the smaller root systems, the estimated time before the lateral roots overlapped with adjacent plants varied from 5.5 years (Leptospermum scoparium), 6.8 years (Knightia excelsa), and 8.7 years (Myrsine australis). In a similar exercise, Marden et al. (2018, in press) concluded that the root systems of broadleaved Vitex lucens and Alectryon excelsus would likely overlap with those of adjacent plants when 5 years old, and earlier than for the best 


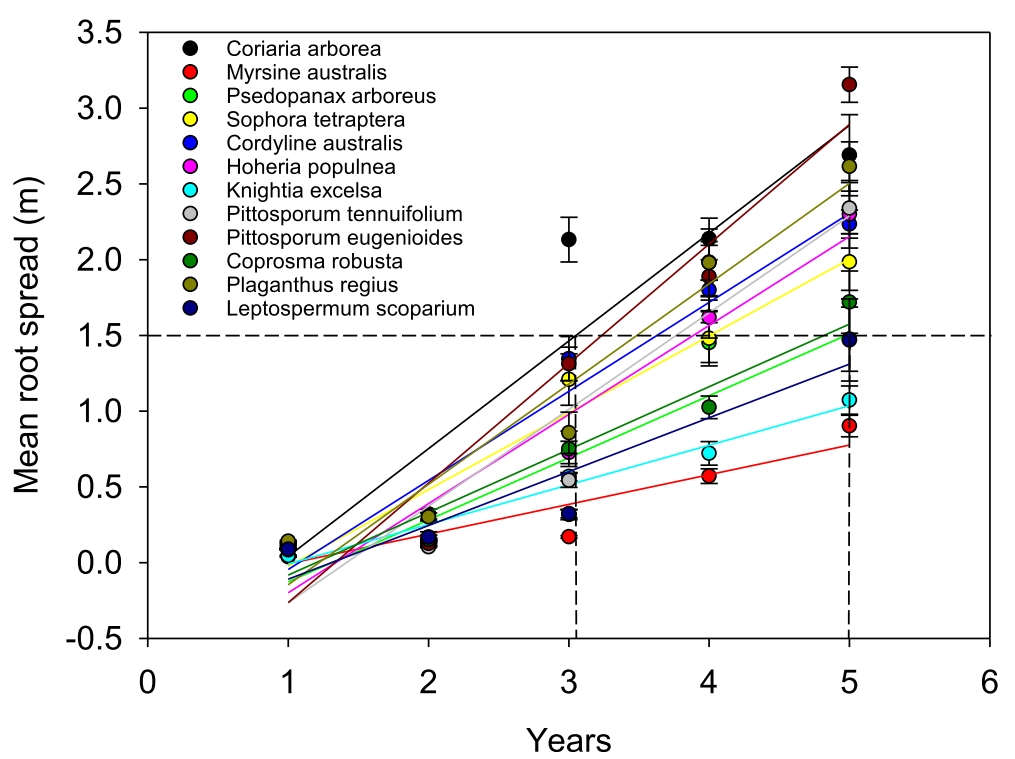

Fig. 6 Time required for roots of plants at $3 \times 3 \mathrm{~m}$ spacing $\left(1100\right.$ stems ha $\left.{ }^{-1}\right)$ to overlap. Error bars represent the standard error of the mean. The line at $1.5 \mathrm{~m}$ indicates which species and the year their lateral roots extended half the distance between plants

performed conifer Podocarpus totara. Furthermore, it was considered unlikely that the smaller and more compact root systems of the slower growing conifers including Prumnopitus taxifolia, Prumnopitus ferruginea, and Dacrydium cupressinum would provide sufficient root overlap to prevent the initiation of shallow landslides for at least $\sim 10-15$ years after establishment.

Of the trialled species, mānuka is the only species currently being planted as a monoculture across extensive areas of hill country formerly used for farming. The most likely scenario for transitioning further areas of the more erosion-prone hill country to an indigenous shrubland/forest will involve the establishment of mixed plantings of indigenous species. Based on the above- and below-ground growth metrics of the trialled species, a selection of the best-performed of them established at 1100 stems $\mathrm{ha}^{-1}$ would mitigate surface erosion processes within 2 years. These processes include rain splash, slope wash, and minor rilling typically associated with landslide-prone pastoral hill country but more so with areas of exotic forest cutover (Marden and Rowan 1997; Marden et al. 2006, 2007). Within 5 years, planting would likely provide minimal protection against the initiation of shallow landslides during extreme storm events, but as has been previously demonstrated in areas of natural reversion subjected to such events, the level of protection increases with increasing age/maturity of the plantings. By implication, and assuming that the initial planting density is maintained (i.e. survival of $\geq 90 \%$ of establishment plantings), the expectation is that new plantings will afford a moderate level of protection by year 8 and a high level of protection by year 16 .
An alternative planting strategy used to minimise the number of years after planting that plantings are at greatest risk to the initiation of landslides is to increase the planting density so that soil-root reinforcement together with the hydrological benefits of a closed canopy occurs earlier which in turn significantly improves the likelihood of a successful erosion control outcome.

\section{Conclusions}

Informed decisions on the species mix and density of plantings most suited to stabilising shallow landslides and small-scale, deeper-seated slope failures are reliant on knowledge of root system type, growth rate and spatial distribution of the root biomass and root length, and the range and distribution of root size classes relative to depth and distance from the root bole.

This trial has provided new information showing that seral species are sufficiently diverse in rooting form to improve the stability of slopes prone to shallow forms of erosion. Based on root system architecture (e.g. the spatial distribution of roots by width and depth) and root metrics (e.g. total root length, root diameter size, and root biomass), the species most likely to restore stability to marginal pastoral or retired areas of exotic forest quickest include the tap-rooted Cordyline australis and the heart-rooted Pittosporum tenuifolium, Pittosporum eugenioides, Plagianthus regius, Coriaria arborea, and Hoheria populnea. Although the root systems of these heart-rooted species comprised an unevenly distributed network of spindly and largely surficial structural roots, their total root biomass and root length - the factors most commonly used to infer the potential soil-reinforcing ability of different 
species-was superior to that of the remaining heart-rooted species. With increasing age, these species will afford greater surficial stability over a wider area than will the predominantly fibrous and smaller-diameter root systems of Myrsine australis, Knightia excelsa, and Leptospermum scoparium.

Established at 1100 stems per hectare, mixed-species plantings of the best performed of the trialled species would mitigate surface erosion processes (rain splash, slope wash, and minor rilling) within 2 years of establishment but are unlikely to moderate the initiation of shallow landslides during extreme storm events until plantings are $\geq$ 8 years old. The likelihood of a successful erosion control outcome increases significantly if plantings are established at higher densities (e.g. 2000 stems ha $^{-1}$ ) as long as survival rates are $\geq 90 \%$ of establishment plantings.

The comparison of slopes of the regression curves generated in a linear analysis of RCD (over bark) and total root length for roots $>1$ and $>2 \mathrm{~mm}$ diameter indicated that as RCD increases, the increase in the length of roots in the $1-2-\mathrm{mm}$ diameter size range is greater than for the other root size classes. Thus, analyses that exclude roots in the $1-2-\mathrm{mm}$ diameter size class would not be representative of the changes in apportionment of total root length by root diameter size with increasing age. It is therefore recommended that when modelling root-soil reinforcement and the role of root systems in mitigating the initiation of shallow slope failures, analyses of total root length and biomass include all roots > $1 \mathrm{~mm}$ in diameter.

Integral to the development of guidelines and policy for land use conversion on erodible marginal land, and its future management towards a continuous and permanent forest cover, are further studies of the aboveand below-ground growth rates of species comprising different indigenous shrub and tree associations across a range of New Zealand's natural geomorphic settings.

\section{Additional file}

Additional file 1: Plan and side views of root systems of 5-year-old plants. (PDF $569 \mathrm{~kb}$ )

\section{Abbreviations}

AGB: Above-ground biomass; BGB: Below-ground biomass; DBH: Diameter at breast height; RCD: Root collar diameter; Stems/ha: Stems per hectare

\footnotetext{
Acknowledgements

We acknowledge the support of the Tairawhiti Polytechnic Rural Studies Unit, Gisborne, on whose land the riparian plant trial was located. Sketches were drawn by local artist Graham Mudge. Graphics were drawn by Nicolette Faville. Anne Austin and Ray Prebble edited the manuscript. Robyn Simcock reviewed the manuscript and provided valuable comment. Thanks also to the anonymous external reviewers for their valuable comment. This research was supported by funding from the New Zealand Ministry of Business, Innovation and Employment (MBIE), Specific Science Investment Fund (SSIF), 'Growing Confidence in Forestry's Future' research programme
}

(contract CO4X1306), and 'Clean Water Productive Land' research programme (contract C10X1006).

\section{Availability of data and materials}

Please contact the author for data requests.

\section{Authors' contributions}

MM was the primary author. MM and DR designed and established the trial site, excavated and measured plant metrics, and compiled the database. $\mathrm{SL}$ completed the statistical analyses and most of the tables and figures. All authors read and approved the manuscript.

Ethics approval and consent to participate

Not applicable.

\section{Competing interests}

The authors declare that they have no competing interests.

\section{Publisher's Note}

Springer Nature remains neutral with regard to jurisdictional claims in published maps and institutional affiliations.

\section{Author details}

${ }^{1}$ Landcare Research, Gisborne, New Zealand. ${ }^{2}$ Landcare Research, Private Bag 3127, Hamilton 3240, New Zealand. 'Whangarei, New Zealand.

Received: 3 January 2018 Accepted: 18 May 2018

Published online: 11 July 2018

\section{References}

Aldridge, R, \& Jackson, RJ. (1968). Interception of rainfall by manuka (Leptospermum Scoparium) at Taita, New Zealand. New Zealand Journal of Science, 11(2), 301-317.

Aldridge, R, \& Jackson, RJ. (1973). Interception of rainfall by hard beech (Nothofagus trunccita) at Taita, New Zealand. New Zealand Journal of Science, 16, 185-198.

Allan Herbarium (2000). New Zealand plant names database. New Zealand: Landcare Research Retrieved from: http://nzflora.landcareresearch.co.nz. Accessed 15 Jan 2005.

Beets, PN, Pearce, SH, Oliver, GR, Clinton, PW. (2007). Root:shoot ratios for deriving below-ground biomass of Pinus radiata stands. New Zealand Journal of Forestry Science, 37(2), 267-288.

Blake, GJ. (1965). Measurement of interception loss in tea tree. Abstract. Journal of Hydrology (New Zealand), 4, 87.

Cairns, MA, Brown, S, Helmer, EH, Baumgardner, GA. (1997). Root biomass allocation in the world's upland forests. Oecologia, 111, 1-11.

Clark, LJ, Price, AH, Steel, KA, Whalley, WR. (2008). Evidence from near-isogenic lines that root penetration increases with root diameter and bending stiffness in rice. Functional Plant Biology, 35, 1163-1171.

Coomes, DA, Allen, RB, Scott, NA, Goulding, C, Beets, P. (2002). Designing systems to monitor carbon stocks in forests and shrublands. Forest Ecology and Management, 164, 89-108.

Czernin, A, \& Phillips, CJ. (2005). Below-ground morphology of Cordyline australis (New Zealand cabbage tree) and its suitability for riverbank stabilisation. New Zealand Journal of Botany, 43, 851-864.

Ekanayake, JC, Marden, M, Watson, AJ, Rowan, D. (1997). Tree roots and slope stability: a comparison between Pinus radiata and kānuka. New Zealand Journal of Forestry Science, 27(2), 216-233.

Hall, G, Wiser, S, Allen, R, Beets, P, Goulding, C. (2001). Strategies to estimate national forest carbon stocks from inventory data: the 1990 New Zealand baseline. Global Change Biology, 7, 389-403.

Heth, D, \& Donald, DGM. (1978). Root biomass of Pinus radiata D. Don. South Africa Forestry Journal, 107, 60-70.

Hewitt, A. E. (2010). New Zealand soil classification. Landcare Research Science Series No. 1. Lincoln: Manaaki Whenua Press.

Hinds, HV, \& Reed, JS. (1957). Forest Trees and Timber of New Zealand. New Zealand Forest Service Bulletin, 12, 221p.

Hruska, J, Cermak, J, Sustek, S. (1999). Mapping tree root systems with groundpenetrating radar. Tree Physiology, 19, 125-130.

Jackson, RJ, \& Aldridge, R. (1973). Interception of rainfall by kamahi (Weinmannia racemosa) at Taita, New Zealand. New Zealand Journal of Science, 16, 573-590. 
Kelliher, FM, Whitehead, D, Pollock, DS. (1992). Rainfall interception by trees and slash in a young Pinus radiata D. Don stand. Journal of Hydrology, 131, 187-204.

Ketterings, QM, Coe, R, van Noordwijk, M, Ambagau, Y, Palm, CA. (2001). Reducing uncertainty in the use of allometric biomass equations for predicting above-ground tree biomass in the mixed secondary forests. Forest Ecology and Management, 146, 199-209.

Korner, C. (1998). A re-assessment of high elevation tree line positions and their explanation. Oecologia, 115, 445-459.

Marden, M, \& Lambie, S (2016). Plot-based, growth performance of space-planted mānuka (Leptospermum scoparium) on marginal land, and vulnerability to erosion. Ministry for Primary Industries Technical Paper No. 2016/20. http:// www.mpi.govt.nz/news-resources-publications.aspx/ Accessed 30 August 2016.

Marden, M, Lambie, S, \& Phillips, CJ (2018). Biomass and root attributes of eight of New Zealand's most common indigenous evergreen conifer and broadleaved forest species during the first 5-years of establishment. New Zealand Journal of Forestry Science, 48: 9 https://doi.org/10.1186/s40490-0180113-y

Marden, M, Phillips, CJ, \& Rowan, D (1991). Declining soil loss with increasing age of plantation forest in the Uawa catchment, East Coast region, North Island, New Zealand. In: Proceedings of the International Conference on Sustainable Land Management (pp. 358-361), Napier, New Zealand.

Marden, M, \& Rowan, D. (1993). Protective value of vegetation on Tertiary terrain before and during Cyclone Bola, East Coast, North Island, New Zealand. New Zealand Journal of Forestry Science, 23, 255-263.

Marden, M, \& Rowan, D. (1997). Vegetation recovery and indicative sediment generation rates by sheetwash erosion from hauler-logged settings in Mangatu Forest. New Zealand Journal of Forestry, 42, 29-34.

Marden, M, Rowan, D, Lambie, S. (2016). Root development and whole-tree allometry of juvenile trees of five seed lots of Pinus radiata D.Don: implications for forest establishment on erosion-prone terrain, East Coast region, North Island, New Zealand. New Zealand Journal of Forestry Science, 46: 24

Marden, M, Rowan, D, Phillips, C (1995). Impact of cyclone-induced landsliding on plantation forests and farmland in the East Coast region of New Zealand: a lesson in risk management. In Proceedings of the XX IUFRO World Congress, Finland: Technical session on Natural Disasters in Mountainous Areas, (pp. 133-145).

Marden, M, Rowan, D, Phillips, C. (2005). Stabilising characteristics of New Zealand indigenous riparian colonising plants. Plant and Soil, 278, 95-105. https://doi. org/10.1007/s11104-004-7598-2.

Marden, M, Rowan, D, Phillips, C. (2006). Sediment sources and delivery following plantation harvesting in a weathered volcanic terrain, Coromandel Peninsula, North Island, New Zealand. Australian Journal of Soil Research, 44, 219-232.

Marden, M, Rowe, L, Rowan, D. (2007). Slope wash erosion following plantation harvesting in pumice terrain and its contribution to stream sedimentation, Pokairoa catchment, North Island, New Zealand. Journal of Hydrology (NZ), 46, 73-90.

Ministry for Primary Industries (2015a). A guide to the Afforestation Grant Scheme. Wellington: Ministry for Primary Industries http://www.mpi.govt.nz/funding-andprogrammes/forestry/afforestation-grant-scheme/. Accessed 21 May 2017.

Ministry for Primary Industries (2015b). A guide to the Permanent Forest Sink Initiative. Wellington: Ministry for Primary Industries http://www.mpi.govt.nz/ funding-and-programmes/forestry/permanent-forest-sink-initiative/ afforestation. Accessed 2 Aug 2016.

Ministry for Primary Industries (2016). A quide to the Erosion Control Funding Programme (East Coast). Wellington: Ministry for Primary Industries http:// www.mpi.govt.nz/funding-and-programmes/forestry/erosion-control-fundingprogramme/. Accessed 2 Aug 2016.

Ministry for Primary Industries (2017). A guide to carbon look-up tables for forestry in the Emissions Trading Scheme. Wellington: Ministry for Primary Industries http://www.mpi.govt.nz/growing-and-producing/forestry/forestry-in-theemmissions-trading-scheme/emissions-returns/. Accessed 11 Sept 2017.

New Zealand Meteorological Service (1986). Summäries of water balance data for New Zealand stations. Wellington: New Zealand Meteorological Service Publication no. 189

Page, MJ, Trustrum, NA, De Rose, RC. (1994). A high-resolution record of storminduced erosion from lake sediments, New Zealand. Journal of Paleolimnology, 11, 333-348.

Pearce, AJ, O'Loughlin, CL, Jackson, RJ, Zhang, XB (1987). Reforestation: on-site effects on hydrology and erosion, eastern Raukumara Range, New Zealand. In: R. H. Swanson, P. Y. Bernier, P. D. Woodard (Eds.), Forest Hydrology and Watershed Management. International Association of Hydrological Sciences Publication. 167. Pp. 489-497.
Phillips, CJ, Marden, M, Lambie, MS. (2014). Observations of root growth of young poplar and willow planting types. New Zealand Journal of Forestry Science, 44: 15. https://doi.org/10.1186/s40490-014-0015-6

Phillips, CJ, Marden, M, Lambie, MS, Watson, AJ, Ross, C, Fraser, S. (2012). Observations of below-ground characteristics of young redwood trees (Sequoia sempervirens) from two sites in New Zealand: implications for erosion control. Plant and Soil. https://doi.org/10.1007/s11104-012-1286-4 http://www.nzjforestryscience.com/content/44/1/15. Accessed 11 June 2012.

Phillips, CJ, Marden, M, Lambie, S. (2015). Observations of "coarse" root development in young trees of nine exotic species from a New Zealand plot trial. New Zealand Journal of Forestry Science 45:13. https://doi.org/10.1186/ s40490-015-0043-X

Phillips, CJ, Marden, M, Rowan, D, Ekanayake, JC (2001). Stabilising characteristics of native riparian vegetation in New Zealand. In Proceedings of $3 \mathrm{rd}$ Australian Stream Management Conference, Brisbane, August 2001, (pp. 507-512).

Phillips, CJ, \& Watson, AJ (1994). Structural tree root research in New Zealand, a review. In Landcare Research Science Series 7. Lincoln: Manaaki Whenua Press.

Pollock, K. M. (1986). Plant materials handbook for soil conservation, Vol 3: native plants. Water and Soil Miscellaneous Publications No. 95. Palmerston North: Soil Conservation Centre, Ministry of Works and Development.

Rowe, LK, Marden, M, Rowan, D. (1999). Interception and throughfall of kanuka (Kunzea ericoides var. ericoides), East Coast region, North Island, New Zealand, and implications for soil conservation. Journal of Hydrology (NZ), 38(1), 29-48.

Salter, RT, Crippen, TF, Noble, KE (1983). Storm damage assessment of the Thame'sTe Aroha area following the storm of April 1981. Palmerston North: National Water and Soil Conservation Authority.

Schmidt, KM, Roering, JJ, Stock, JD, Dietrich, WE, Montgomery, DR, Schaub, T. (2001). Root cohesion variability and shallow landslide susceptibility in the Oregon Coast Range. Canadian Geotechnical Journal, 38, 995-1024.

Schwarz, M, Lehmann, P, Or, D. (2010). Quantifying lateral root reinforcement in steep slopes from a bundle of roots to tree stands. Earth Surface Processes and Landforms, 35(3), 354-367. https://doi.org/10.1002/esp.1927.

Selby, MJ. (1976). Slope erosion due to extreme rainfall: a case study from New Zealand. Geografiska Annaler. Series A Physical Geography, 58(3), 131-138.

Swanston, DN, \& Swanson, FJ (1976). Timber harvesting, mass erosion, and steepland forest geomorphology in the Pacific North West. In DR Coates (Ed.), Geomorphology and Engineering, (pp. 199-221). Stroudsburg: Dowden, Hutchinson, and Ross.

Trotter, C, Tate, K, Scott, N, Townsend, J, Wilde, H, Lambie, S, Marden, M, Pinkney, T. (2005). Afforestation/reforestation of New Zealand marginal pasture lands by indigenous shrub lands: the potential for Kyoto forest sinks. Annals of Forestry Science, 62, 865-871.

Wagner, RG, \& Ter-Mikaelian, MT. (1999). Comparison of biomass component equations for four species of northern coniferous tree seedlings. Annals of Forestry Science, 56, 193-199.

Watson, AJ, Marden, M, Rowan, D (1995). Tree species performance and slope stability. In DH Barker (Ed.), Vegetation and slopes, (pp. 161-171). London: Thomas Telford Press.

Watson, AJ, \& O'Loughlin, CL. (1985). Morphology, strength, and biomass of mānuka roots and their influence on slope stability. New Zealand Journal of Forestry Science, 15(3), 337-348.

Watson, AJ, \& O'Loughlin, CL. (1990). Structural root morphology and biomass of three age classes of Pinus radiata. New Zealand Journal of Forestry Science, 20(1), 97-110.

Watson, AJ, Phillips, CJ, Marden, M. (1999). Root strength, growth, and rates of decay: root reinforcement changes of two tree species and their contribution to slope stability. Plant and Soil, 217, 39-47.

Watson, AJ, \& Tombleson, JD. (2002). Toppling in juvenile pines: a comparison of the root system characteristics of direct-sown seedlings, and bare-root seedlings and cuttings. Plant and Soil, 239, 187-196.

Watson, AJ, \& Tombleson, JD. (2004). Toppling in young pines: temporal changes in root system characteristics of bare-root seedlings and cuttings. New Zealand Journal of Forestry Science, 34(1), 39-48.

Will, GM (1966). Root growth and dry-matter production in a high-producing stand of Pinus radiata. Research Notes 44. Rotorua: New Zealand Forest Service, Forest Research Institute.

Wu, TH, McKinnel, WP, Swanston, DN. (1979). Strength of tree roots and landslides on Prince of Wales Island. Alaska Canadian Geotechnical Journal, 16, 19-33. 